\title{
Identification of QTL markers contributing to plant growth, oil yield and fatty acid composition in the oilseed crop Jatropha curcas L.
}

Andrew J. King ${ }^{1 *+}$, Luis R. Montes ${ }^{2,3,4 \dagger}$, Jasper G. Clarke ${ }^{1+}$, Jose Itzep², Cesar A. A. Perez ${ }^{6}$, Raymond E. E. Jongschaap ${ }^{5}$, Richard G. F. Visser ${ }^{3}$, Eibertus N. van Loo ${ }^{3^{*}}$ and lan A. Graham*

\begin{abstract}
Background: Economical cultivation of the oilseed crop Jatropha curcas is currently hampered in part due to the non-availability of purpose-bred cultivars. Although genetic maps and genome sequence data exist for this crop, marker-assisted breeding has not yet been implemented due to a lack of available marker-trait association studies. To identify the location of beneficial alleles for use in plant breeding, we performed quantitative trait loci (QTL) analysis for a number of agronomic traits in two biparental mapping populations.

Results: The mapping populations segregated for a range of traits contributing to oil yield, including plant height, stem diameter, number of branches, total seeds per plant, 100-seed weight, seed oil content and fatty acid composition. QTL were detected for each of these traits and often over multiple years, with some variation in the phenotypic variance explained between different years. In one of the mapping populations where we recorded vegetative traits, we also observed co-localization of QTL for stem diameter and plant height, which were both overdominant, suggesting a possible locus conferring a pleotropic heterosis effect. By using a candidate gene approach and integrating physical mapping data from a recent high-quality release of the Jatropha genome, we were also able to position a large number of genes involved in the biosynthesis of storage lipids onto the genetic map. By comparing the position of these genes with QTL, we were able to detect a number of genes potentially underlying seed traits, including phosphatidate phosphatase genes.

Conclusions: The QTL we have identified will serve as a useful starting point in the creation of new varieties of J. curcas with improved agronomic performance for seed and oil productivity. Our ability to physically map a significant proportion of the Jatropha genome sequence onto our genetic map could also prove useful in identifying the genes underlying particular traits, allowing more controlled and precise introgression of desirable alleles and permitting the pyramiding or stacking of multiple QTL.
\end{abstract}

Keywords: Jatropha curcas, Linkage mapping, QTL analysis, Oil content, Seed weight, Seed yield

\footnotetext{
*Correspondence: andy.king@york.ac.uk; robert.vanloo@wur.nl; ian. graham@york.ac.uk

${ }^{\dagger}$ Andrew J. King, Luis R. Montes and Jasper G. Clarke contributed equally to this manuscript

1 Department of Biology, Centre for Novel Agricultural Products,

University of York, York YO10 5DD, UK

${ }^{3}$ Wageningen UR Plant Breeding, Wageningen University and Research

Centre, PO Box 386, 6700 AJ Wageningen, The Netherlands

Full list of author information is available at the end of the article
} 


\section{Background}

Jatropha curcas L. is a perennial oilseed crop which is suitable for cultivation in tropical and sub-tropical regions [1]. At present, the economic cultivation of this orphan crop is hampered by a number of factors. As $J$. curcas cultivation has only occurred sporadically on a relatively small scale, there is currently limited knowledge of the agronomy of this crop, and the reported yields obtained so far vary significantly. While seed yields of up to 3-4 tonnes per hectare can be achieved under controlled conditions [2-4], "farm" yields are typically much lower $[5,6]$ and well below "projections" that have been indicated in a number of reports (summarized in Heller [7]). Economic cultivation of Jatropha has also been hampered by the lack of purpose-bred cultivars and the reliance on genetically homogeneous plants that are likely to be descended from very limited germplasm that was originally transported to Cape Verde by the Portuguese during colonial times [7]. J. curcas is native to Mesoamerica, and analyses performed using robust markers such as amplified fragment length polymorphism (AFLP), single nucleotide polymorphisms (SNP) and simple sequence repeats (SSR) have indicated that the material currently grown in Africa, Asia and South America is almost clonal [9-11]. Significant genetic variation, however, has been reported in Mesoamerica, particularly in Guatemala and the state of Chiapas in Mexico [9, 10, 12, 13]. These Mesoamerican provenances of $J$. curcas therefore represent a valuable germplasm resource for the purpose of breeding. As a first step in developing a molecular breeding programme for the improvement of J. curcas, we recently constructed a genetic linkage map for this species [14]. We have previously used this map to identify, to within $2.3 \mathrm{cM}$, a locus responsible for the loss of phorbol ester biosynthesis in "non-toxic" types of J. curcas. These phorbol esters are not removed by conventional seed meal processing methods and make the use of the proteinrich seed meal obtained from most "varieties" of J. curcas unsuitable for use as animal feed $[9,15]$. As well as identifying loci controlling qualitative Mendelian traits, mapping populations can also be used to find quantitative trait loci (QTL), i.e. regions of the genome contributing to complex multigenic traits which are scored as continuous data. QTL mapping has previously been conducted on an interspecific cross between J. curcas and J. integerrima, resulting in the identification of loci contributing to seed weight, fatty acid composition and vegetative growth characteristics (including height and branching) $[16,17]$. Although these QTL are useful for identifying beneficial (as well as non-desirable) loci for breeding of new plant varieties containing chromosomal introgressions from $J$. integerrima, this interspecific mapping population approach cannot identify beneficial alleles present within the J. curcas germplasm. For this purpose, we collected phenotypic data from two different mapping populations incorporating "wild" provenances collected from Guatemala. Within these populations we identified QTL for a number of agronomic traits including plant height, stem diameter, canopy area, number of branches, 100 -seed weight and seed oil content, many of which appeared to be stable over multiple harvest years. Pyramiding of these QTL in other genetic backgrounds could lead to the creation of improved cultivars more suited to the commercial production of vegetable oil and animal feed from this orphan crop. We also present an updated genetic linkage map for Jatropha containing additional markers, onto which we mapped scaffolds from a recent high-quality draft of the J. curcas genome [18], and discuss the utility of this approach in identifying candidate genes underlying important QTL.

\section{Results and discussion}

\section{An updated genetic linkage map for Jatropha curcas}

We recently published the first intraspecies linkage map for $J$. curcas [14]. The combined map, which was based on four $\mathrm{F}_{2}$ mapping populations, contained 502 markers spanning a total distance of $717 \mathrm{cM}$. To improve the density of individual maps and add candidate genes that may contribute to specific traits, we developed a number of additional SSR markers which are detailed in Additional file 1: Table S1. The revised genetic linkage map, which now contains 587 markers spanning a total distance of $673 \mathrm{cM}$, is shown in Figs. 1 and 2. A summary of the markers, marker densities and genetic distances for each of the linkage groups is shown in Table 1. The increase in the number of markers, together with a small reduction in the overall calculated map length, has resulted in a modest improvement in mean marker density of $0.3 \mathrm{cM}$; our latest map has a density of $1.2 \mathrm{cM}$ per marker or $1.5 \mathrm{cM}$ per unique locus, compared with 1.5 and $1.8 \mathrm{cM}$, respectively, in our previous map.

Previously, using the draft genome assembly released by the Kazusa DNA Research Institute [19, 20], we were able to physically map $17 \mathrm{Mbp}$ (of $297 \mathrm{Mbp}$ ) of genome sequence against our genetic linkage map. Within this $17 \mathrm{Mbp}$ were 3077 of the 39,277 predicted gene models [14]. This represents $5.7 \%$ of the genome and $7.8 \%$ of the predicted genes for this version of genome assembly. The ability to map a greater proportion of the genome would be beneficial in allowing the position of candidate genes likely to correspond to particular traits to be mapped. Recently, the Chinese Academy of Sciences (CAS) has also released a J. curcas genome [18]. This genome was obtained from sequencing to a depth of 189-fold, and contains scaffolds with an N50 of 746,835 compared to the Kazusa DNA Research Institute 


\section{Linkage Group 1}

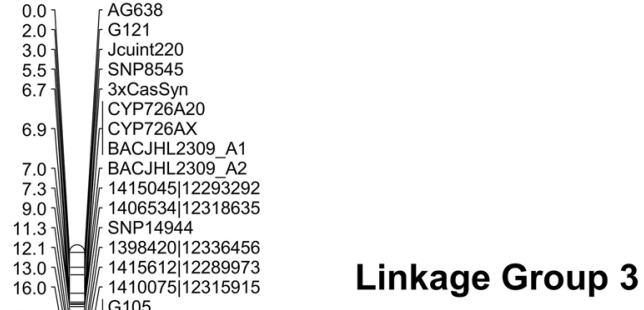

Linkage Group 5
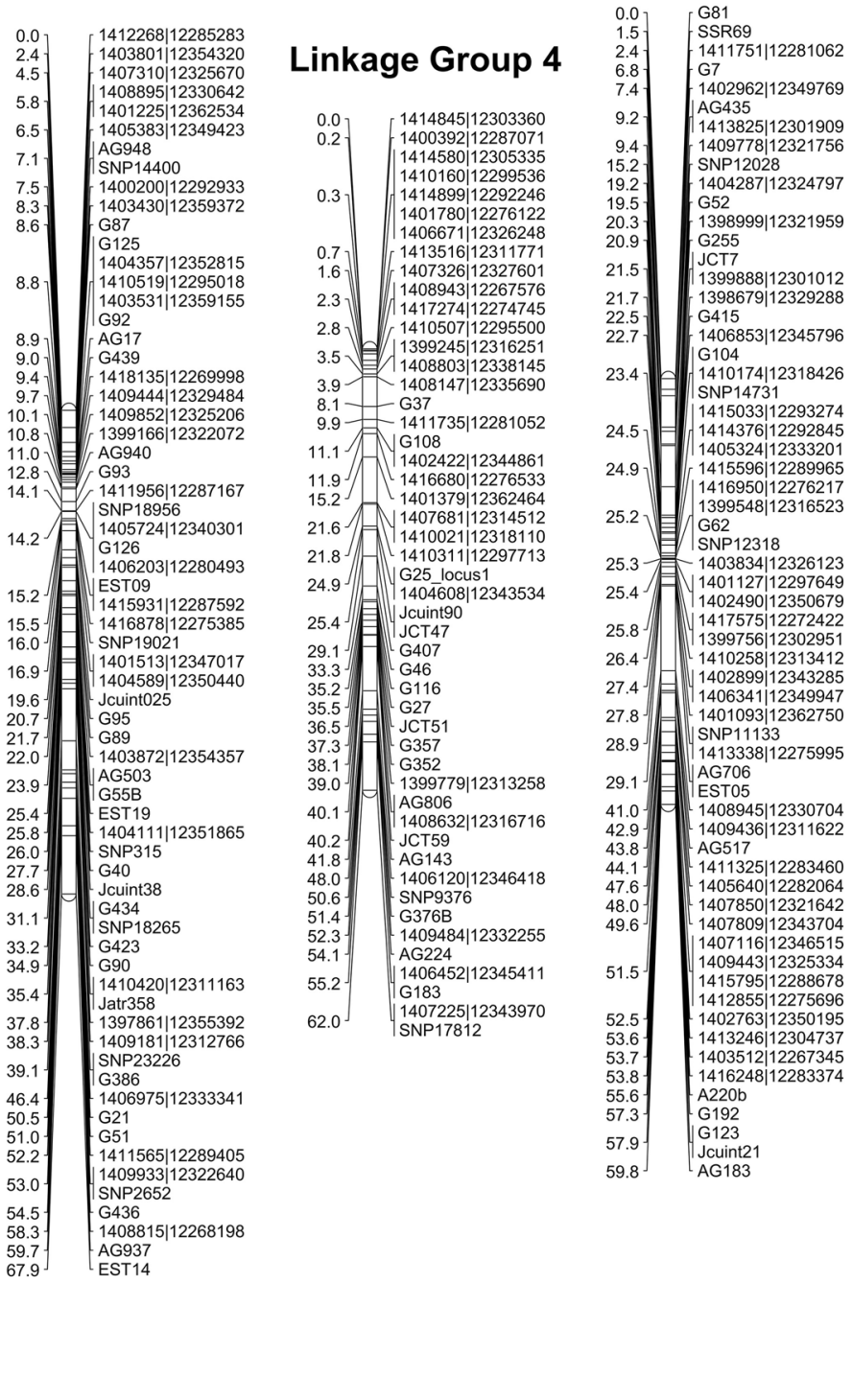

Fig. 1 Linkage groups 1-5 of the combined J. curcas linkage map. Positions of markers are shown in cM (Kosambi) 


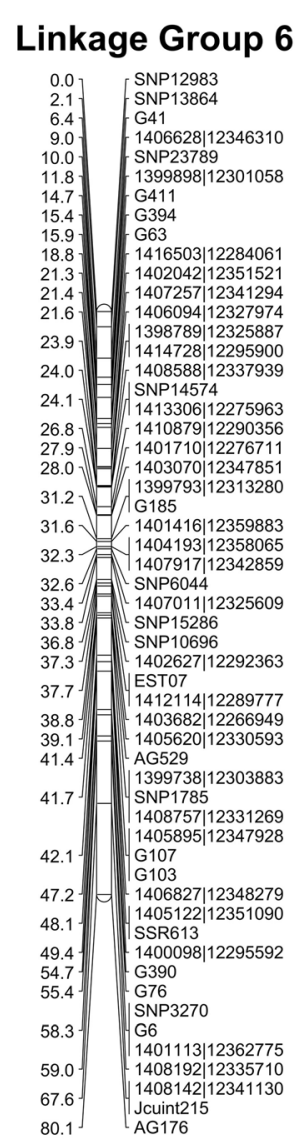

\section{Linkage Group 7}

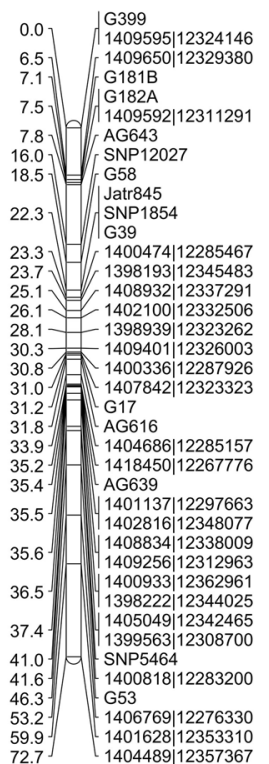

\section{Linkage Group 8}

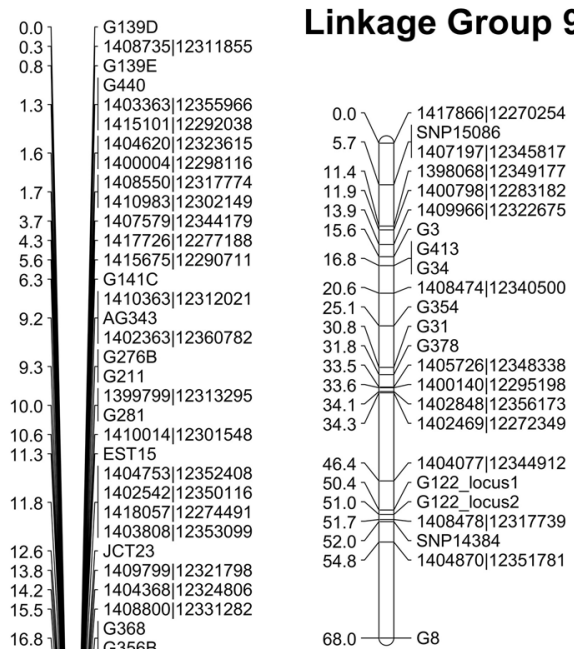

\section{Linkage Group 10}

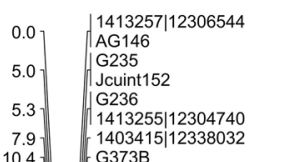

Linkage Group 11

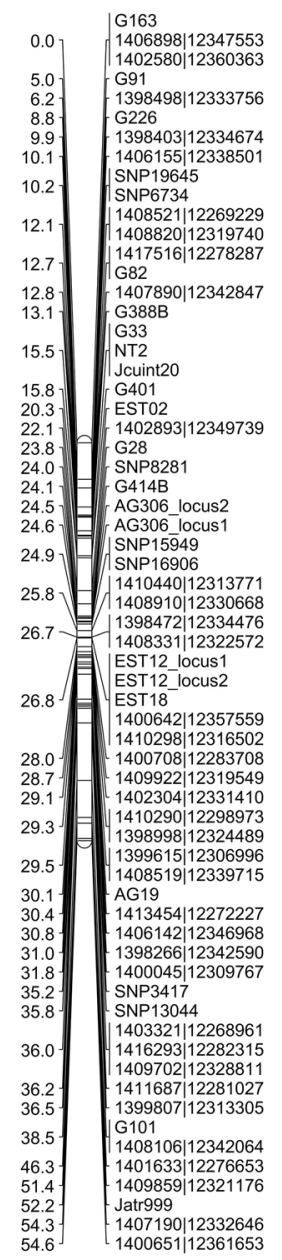

Fig. 2 Linkage groups 6-11 of the combined J. curcas linkage map. Positions of markers are shown in cM (Kosambi)

version 4.5, which has an N50 of 15,950. This improved genome assembly provided us with the opportunity to physically map a substantial amount of the genome against our genetic linkage map. After conducting BlastN searches of our molecular markers against this new version of the genome, we were able to map a total 
Table 1 Summary statistics of the J. curcas combined linkage map

\begin{tabular}{|c|c|c|c|c|c|c|c|}
\hline Linkage group & Markers & Unique loci & Length (cM) & $\begin{array}{l}\text { Marker } \\
\text { density (All) }\end{array}$ & $\begin{array}{l}\text { Marker } \\
\text { density (Unique) }\end{array}$ & $\begin{array}{l}\text { Genome mapped } \\
\text { (Mbp) }\end{array}$ & $\begin{array}{l}\text { Gene models } \\
\text { mapped }\end{array}$ \\
\hline 1 & 44 & 35 & 49.3 & 1.1 & 1.4 & 12.3 & 1495 \\
\hline 2 & 41 & 34 & 74.5 & 1.9 & 2.3 & 15.8 & 1609 \\
\hline 3 & 66 & 52 & 67.9 & 1.0 & 1.3 & 20.4 & 1435 \\
\hline 4 & 49 & 37 & 62.0 & 1.3 & 1.7 & 11.7 & 1343 \\
\hline 5 & 62 & 47 & 59.8 & 1.0 & 1.3 & 14.3 & 1661 \\
\hline 6 & 55 & 55 & 43.0 & 0.8 & 0.8 & 15.9 & 1960 \\
\hline 7 & 39 & 32 & 72.7 & 1.9 & 2.3 & 19.1 & 2007 \\
\hline 8 & 94 & 71 & 66.8 & 0.7 & 1.0 & 13.5 & 1737 \\
\hline 9 & 24 & 23 & 68.0 & 3.0 & 3.1 & 9.9 & 1242 \\
\hline 10 & 49 & 32 & 54.6 & 1.1 & 1.8 & 14.0 & 1343 \\
\hline 11 & 64 & 47 & 54.6 & 0.9 & 1.2 & 15.2 & 1620 \\
\hline Total & 587 & 465 & 673.2 & 1.2 & 1.5 & 162.2 & 17,452 \\
\hline
\end{tabular}

Table 2 Pearson correlations and $p$ values for vegetative and oil yield traits in mapping population G51 x CV

\begin{tabular}{|c|c|c|c|c|c|c|c|c|c|c|c|c|c|c|c|c|c|c|c|}
\hline & 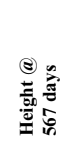 & 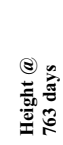 & 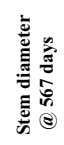 & 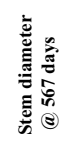 & 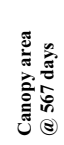 & 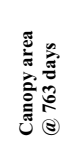 & 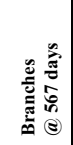 & 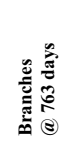 & 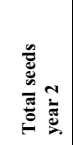 & 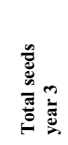 & 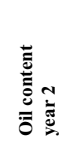 & 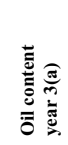 & 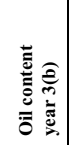 & 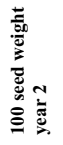 & 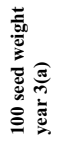 & 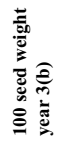 & 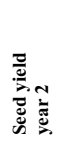 & 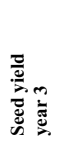 & 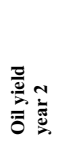 \\
\hline $\begin{array}{r}\text { Height @ } \\
763 \text { days } \\
\end{array}$ & $\begin{array}{l}0.831 \\
0.000 \\
\end{array}$ & & & & & & & & & & & & & & & & & & \\
\hline $\begin{array}{r}\text { Stem diameter } \\
\text { a } 567 \text { days } \\
\end{array}$ & $\begin{array}{c}0.710 \\
0.000\end{array}$ & $\begin{array}{l}0.596 \\
0.000\end{array}$ & & & & & & & & & & & & & & & & & \\
\hline $\begin{array}{r}\text { Stem diameter } \\
\text { (a) } 763 \text { days }\end{array}$ & $\begin{array}{l}0.693 \\
0.000\end{array}$ & $\begin{array}{l}0.654 \\
0.000\end{array}$ & $\begin{array}{l}0.857 \\
0.000\end{array}$ & & & & & & & & & & & & & & & & \\
\hline $\begin{array}{r}\text { Canopy area } \\
\text { (a) } 567 \text { days }\end{array}$ & $\begin{array}{l}0.569 \\
0.000\end{array}$ & $\begin{array}{l}0.523 \\
0.000\end{array}$ & $\begin{array}{l}0.624 \\
0.000\end{array}$ & $\begin{array}{l}0.608 \\
0.000\end{array}$ & & & & & & & & & & & & & & & \\
\hline $\begin{array}{r}\text { Canopy area } \\
\text { (a) } 763 \text { days }\end{array}$ & $\begin{array}{l}0.596 \\
0.000\end{array}$ & $\begin{array}{l}0.591 \\
0.000\end{array}$ & $\begin{array}{l}0.548 \\
0.000\end{array}$ & $\begin{array}{l}0.624 \\
0.000\end{array}$ & $\begin{array}{l}0.675 \\
0.000\end{array}$ & & & & & & & & & & & & & & \\
\hline $\begin{array}{r}\text { Branches@ } \\
567 \text { days } \\
\end{array}$ & $\begin{array}{l}0.542 \\
0.000\end{array}$ & $\begin{array}{l}0.505 \\
0.000 \\
\end{array}$ & $\begin{array}{l}0.590 \\
0.000\end{array}$ & $\begin{array}{l}0.623 \\
0.000 \\
\end{array}$ & $\begin{array}{l}0.587 \\
0.000\end{array}$ & $\begin{array}{l}0.586 \\
0.000\end{array}$ & & & & & & & & & & & & & \\
\hline $\begin{array}{r}\text { Branches @ } \\
763 \text { days }\end{array}$ & $\begin{array}{l}0.620 \\
0.000\end{array}$ & $\begin{array}{l}0.592 \\
0.000\end{array}$ & $\begin{array}{l}0.618 \\
0.000\end{array}$ & $\begin{array}{l}0.633 \\
0.000\end{array}$ & $\begin{array}{l}0.613 \\
0.000\end{array}$ & $\begin{array}{l}0.585 \\
0.000\end{array}$ & $\begin{array}{l}0.731 \\
0.000\end{array}$ & & & & & & & & & & & & \\
\hline $\begin{array}{r}\text { Total seeds } \\
\text { year } 2 \\
\end{array}$ & $\begin{array}{l}0.381 \\
0.000\end{array}$ & $\begin{array}{l}0.364 \\
0.000\end{array}$ & $\begin{array}{l}0.408 \\
0.000\end{array}$ & $\begin{array}{l}0.426 \\
0.000\end{array}$ & $\begin{array}{l}0.377 \\
0.000\end{array}$ & $\begin{array}{l}0.543 \\
0.000\end{array}$ & $\begin{array}{l}0.375 \\
0.000\end{array}$ & $\begin{array}{l}0.349 \\
0.000\end{array}$ & & & & & & & & & & & \\
\hline $\begin{array}{r}\text { Total seeds } \\
\text { year } 3\end{array}$ & $\begin{array}{l}0.351 \\
0.000\end{array}$ & $\begin{array}{l}0.303 \\
0.000\end{array}$ & $\begin{array}{l}0.274 \\
0.001\end{array}$ & $\begin{array}{l}0.279 \\
0.001\end{array}$ & $\begin{array}{l}0.334 \\
0.000\end{array}$ & $\begin{array}{l}0.446 \\
0.000\end{array}$ & $\begin{array}{l}0.351 \\
0.000\end{array}$ & $\begin{array}{l}0.457 \\
0.000\end{array}$ & $\begin{array}{l}0.568 \\
0.000\end{array}$ & & & & & & & & & & \\
\hline $\begin{array}{r}\text { Oil content } \\
\text { year } 2\end{array}$ & $\begin{array}{r}-0.046 \\
0.584\end{array}$ & $\begin{array}{l}0.037 \\
0.664\end{array}$ & $\begin{array}{l}0.046 \\
0.584\end{array}$ & $\begin{array}{l}0.023 \\
0.786\end{array}$ & $\begin{array}{r}-0.051 \\
0.550\end{array}$ & $\begin{array}{r}-0.044 \\
0.610\end{array}$ & $\begin{array}{l}0.038 \\
0.655\end{array}$ & $\begin{array}{l}0.054 \\
0.527\end{array}$ & $\begin{array}{r}-0.126 \\
0.138\end{array}$ & $\begin{array}{r}-0.098 \\
0.254\end{array}$ & & & & & & & & & \\
\hline $\begin{array}{r}\text { Oil content } \\
\text { year 3(a) }\end{array}$ & $\begin{array}{r}-0.046 \\
0.600\end{array}$ & $\begin{array}{r}-0.031 \\
0.727\end{array}$ & $\begin{array}{l}0.087 \\
0.322\end{array}$ & $\begin{array}{l}0.029 \\
0.743\end{array}$ & $\begin{array}{l}0.113 \\
0.199\end{array}$ & $\begin{array}{r}-0.036 \\
0.682\end{array}$ & $\begin{array}{r}-0.034 \\
0.703 \\
\end{array}$ & $\begin{array}{l}0.109 \\
0.212\end{array}$ & $\begin{array}{l}0.055 \\
0.535\end{array}$ & $\begin{array}{l}0.190 \\
0.029\end{array}$ & $\begin{array}{l}0.482 \\
0.000\end{array}$ & & & & & & & & \\
\hline $\begin{array}{r}\text { Oil content } \\
\text { year 3(b) }\end{array}$ & $\begin{array}{r}-0.038 \\
0.688\end{array}$ & $\begin{array}{r}-0.100 \\
0.296\end{array}$ & $\begin{array}{l}0.030 \\
0.755\end{array}$ & $\begin{array}{r}-0.051 \\
0.595\end{array}$ & $\begin{array}{l}0.114 \\
0.233\end{array}$ & $\begin{array}{r}-0.028 \\
0.772\end{array}$ & $\begin{array}{r}-0.011 \\
0.910\end{array}$ & $\begin{array}{l}0.078 \\
0.413\end{array}$ & $\begin{array}{r}-0.056 \\
0.557\end{array}$ & $\begin{array}{r}-0.070 \\
0.465\end{array}$ & $\begin{array}{l}0.528 \\
0.000\end{array}$ & $\begin{array}{l}0.782 \\
0.000\end{array}$ & & & & & & & \\
\hline $\begin{array}{r}100 \text { seed weight } \\
\text { year } 2 \\
\end{array}$ & $\begin{array}{l}0.064 \\
0.449 \\
\end{array}$ & $\begin{array}{l}0.107 \\
0.208\end{array}$ & $\begin{array}{l}0.200 \\
0.018\end{array}$ & $\begin{array}{l}0.175 \\
0.038\end{array}$ & $\begin{array}{l}0.022 \\
0.799\end{array}$ & $\begin{array}{l}0.087 \\
0.307\end{array}$ & $\begin{array}{r}-0.016 \\
0.852 \\
\end{array}$ & $\begin{array}{l}0.101 \\
0.234\end{array}$ & $\begin{array}{l}0.032 \\
0.704\end{array}$ & $\begin{array}{r}-0.029 \\
0.773 \\
\end{array}$ & $\begin{array}{l}0.434 \\
0.000\end{array}$ & $\begin{array}{l}0.431 \\
0.000\end{array}$ & $\begin{array}{l}0.326 \\
0.000\end{array}$ & & & & & & \\
\hline $\begin{array}{r}100 \text { seed weight } \\
\text { year } 3(a)\end{array}$ & $\begin{array}{l}0.125 \\
0.153\end{array}$ & $\begin{array}{l}0.171 \\
0.051\end{array}$ & $\begin{array}{l}0.200 \\
0.022\end{array}$ & $\begin{array}{l}0.136 \\
0.119\end{array}$ & $\begin{array}{l}0.156 \\
0.073\end{array}$ & $\begin{array}{l}0.060 \\
0.495\end{array}$ & $\begin{array}{r}-0.033 \\
0.710\end{array}$ & $\begin{array}{l}0.121 \\
0.167\end{array}$ & $\begin{array}{l}0.045 \\
0.607\end{array}$ & $\begin{array}{l}0.234 \\
0.007\end{array}$ & $\begin{array}{l}0.373 \\
0.000\end{array}$ & $\begin{array}{l}0.700 \\
0.000\end{array}$ & $\begin{array}{l}0.448 \\
0.000\end{array}$ & $\begin{array}{l}0.615 \\
0.000\end{array}$ & & & & & \\
\hline $\begin{array}{r}100 \text { seed weight } \\
\text { year 3(b) } \\
\end{array}$ & $\begin{array}{l}0.240 \\
0.011 \\
\end{array}$ & $\begin{array}{l}0.250 \\
0.008 \\
\end{array}$ & $\begin{array}{l}0.199 \\
0.036 \\
\end{array}$ & $\begin{array}{l}0.150 \\
0.115 \\
\end{array}$ & $\begin{array}{l}0.181 \\
0.056 \\
\end{array}$ & $\begin{array}{l}0.183 \\
0.054 \\
\end{array}$ & $\begin{array}{l}0.141 \\
0.138 \\
\end{array}$ & $\begin{array}{l}0.202 \\
0.032 \\
\end{array}$ & $\begin{array}{l}0.143 \\
0.132 \\
\end{array}$ & $\begin{array}{l}0.261 \\
0.006 \\
\end{array}$ & $\begin{array}{l}0.390 \\
0.000 \\
\end{array}$ & $\begin{array}{l}0.575 \\
0.000 \\
\end{array}$ & $\begin{array}{l}0.468 \\
0.000 \\
\end{array}$ & $\begin{array}{l}0.654 \\
0.000 \\
\end{array}$ & $\begin{array}{l}0.815 \\
0.000 \\
\end{array}$ & & & & \\
\hline $\begin{array}{r}\text { Seed yield } \\
\text { year } 2\end{array}$ & $\begin{array}{l}0.320 \\
0.000\end{array}$ & $\begin{array}{l}0.323 \\
0.000\end{array}$ & $\begin{array}{l}0.372 \\
0.000\end{array}$ & $\begin{array}{l}0.383 \\
0.000\end{array}$ & $\begin{array}{l}0.338 \\
0.000\end{array}$ & $\begin{array}{l}0.524 \\
0.000\end{array}$ & $\begin{array}{l}0.318 \\
0.000\end{array}$ & $\begin{array}{l}0.311 \\
0.000\end{array}$ & $\begin{array}{l}0.986 \\
0.000\end{array}$ & $\begin{array}{l}0.554 \\
0.000\end{array}$ & $\begin{array}{r}-0.045 \\
0.601\end{array}$ & $\begin{array}{l}0.139 \\
0.114\end{array}$ & $\begin{array}{l}0.020 \\
0.833\end{array}$ & $\begin{array}{l}0.167 \\
0.049\end{array}$ & $\begin{array}{l}0.147 \\
0.096\end{array}$ & $\begin{array}{l}0.244 \\
0.010\end{array}$ & & & \\
\hline $\begin{array}{r}\text { Seed yield } \\
\text { year } 3\end{array}$ & 0.363 & 0.000 & 0.308 & 0.000 & 0.000 & 0.451 & 0.349 & 0.468 & 0.523 & 0.976 & 0.029 & 0.299 & 0.017 & 0.176 & 0.409 & 0.433 & 0.530 & & \\
\hline $\begin{array}{r}\text { year } 3 \\
\text { Oil yield }\end{array}$ & $\frac{0.000}{0.314}$ & 0.000 & $\frac{0.000}{0.381}$ & $\frac{0.000}{0.384}$ & 0.000 & $\frac{0.000}{0.523}$ & 0.000 & $\begin{array}{l}0.000 \\
0.319\end{array}$ & 0.000 & 0.000 & $\begin{array}{l}0.140 \\
0.050\end{array}$ & 0.000 & $\begin{array}{l}0.803 \\
0.079\end{array}$ & $\begin{array}{l}0.044 \\
0.205\end{array}$ & 0.000 & 0.000 & $\frac{0.000}{0.994}$ & 0.536 & \\
\hline year 2 & 0.000 & 0.000 & 0.000 & 0.000 & 0.000 & 0.000 & 0.000 & 0.000 & 0.000 & 0.000 & 0.560 & 0.035 & 0.410 & 0.015 & 0.035 & 0.002 & 0.000 & 0.000 & \\
\hline $\begin{array}{r}\text { Oil yield } \\
\text { year } 3\end{array}$ & $\begin{array}{l}0.338 \\
0.000\end{array}$ & $\begin{array}{l}0.313 \\
0.000\end{array}$ & $\begin{array}{l}0.307 \\
0.000\end{array}$ & $\begin{array}{l}0.306 \\
0.000\end{array}$ & $\begin{array}{l}0.361 \\
0.000\end{array}$ & $\begin{array}{l}0.431 \\
0.000\end{array}$ & $\begin{array}{l}0.343 \\
0.000\end{array}$ & $\begin{array}{l}0.474 \\
0.000\end{array}$ & $\begin{array}{l}0.490 \\
0.000\end{array}$ & $\begin{array}{l}0.948 \\
0.000\end{array}$ & $\begin{array}{l}0.100 \\
0.254\end{array}$ & $\begin{array}{l}0.402 \\
0.000\end{array}$ & $\begin{array}{l}0.115 \\
0.236\end{array}$ & $\begin{array}{l}0.233 \\
0.007\end{array}$ & $\begin{array}{l}0.470 \\
0.000\end{array}$ & $\begin{array}{l}0.489 \\
0.000\end{array}$ & $\begin{array}{l}0.508 \\
0.000\end{array}$ & $\begin{array}{l}0.990 \\
0.000\end{array}$ & $\begin{array}{l}0.522 \\
0.000\end{array}$ \\
\hline
\end{tabular}

The upper uncoloured cells contain the $R$ values. The lower coloured cells contain the $p$ values. Cells shaded in green represent correlations with a $p$ value $<0.05$, cells shaded in yellow represent a $p$ value of between 0.05 and 0.10 , whereas cells shaded in red represent a $p$ value $>0.10$ (non-significant). Details of data collection and calculation for each trait are provided in "Methods"

of $162 \mathrm{Mbp}$ of the predicted $318 \mathrm{Mbp}$ (i.e. $51 \%$ ) of the CAS Jatropha genome assembly (Table 2 and Additional file 2: Tables S2-S13). This is similar to the value obtained by Wu et al. using our previous generation of the map [18]. In a few instances we observed that some scaffolds mapped to more than one linkage group. This may be due to misassemblies in the published genome sequence or segmental chromosome duplications. In general, however, our mapping order was highly consistent with this draft genome sequence. The scaffolds 
that we were able to map contained 17,452 of 27,172 predicted protein encoding sequences $(64 \%)$ contained within the CAS Jatropha genome (Table 1 and Additional file 2: Table S2).

\section{Positioning markers for storage lipid biosynthesis candidate genes onto the linkage map}

To locate the positions of lipid biosynthesis genes onto our linkage map, we first identified the orthologues of Arabidopsis genes known or suspected to be involved in de novo plastidial lipid biosynthesis and the pathway for the conversion of acyl-CoA into triglycerides, the principal storage lipid in seeds. A diagrammatic representation of these pathways is shown in Fig. 3. In addition to enzymes, we included a number of regulatory proteins. The candidate gene list was compiled from the Arabidopsis AcylLipid Metabolism Website [21]. The genes were identified using BlastP searches of the peptide sequence data for $J$. curcas contained on GenBank. In addition to a number of markers that we developed in close proximity to these candidate genes, we also used the combined genetic and physical map shown in Additional file 2, and the genetic or physical map produced for the interspecific crosses [18, 22 ], and thus were able to identify the positions of almost all of the lipid biosynthesis candidate genes. These genes could potentially be utilized for molecular breeding by the targeted development of additional SNP or SSR markers in the flanking regions of these genes (Additional file 3: Table S14). The limited number of genes involved in lipid biosynthesis that we were unable to map included one isoform of the plasitidial enoyl-acyl carrier protein reductase (step 7 in Fig. 3) which resides on a scaffold we could not map, and a glycerol-3-phosphate acyltransferase isoform and Wrinkled 1 transcription factor isoform which both mapped to part of a (possibly misassembled) scaffold that may be part of linkage group 3 or 8 .

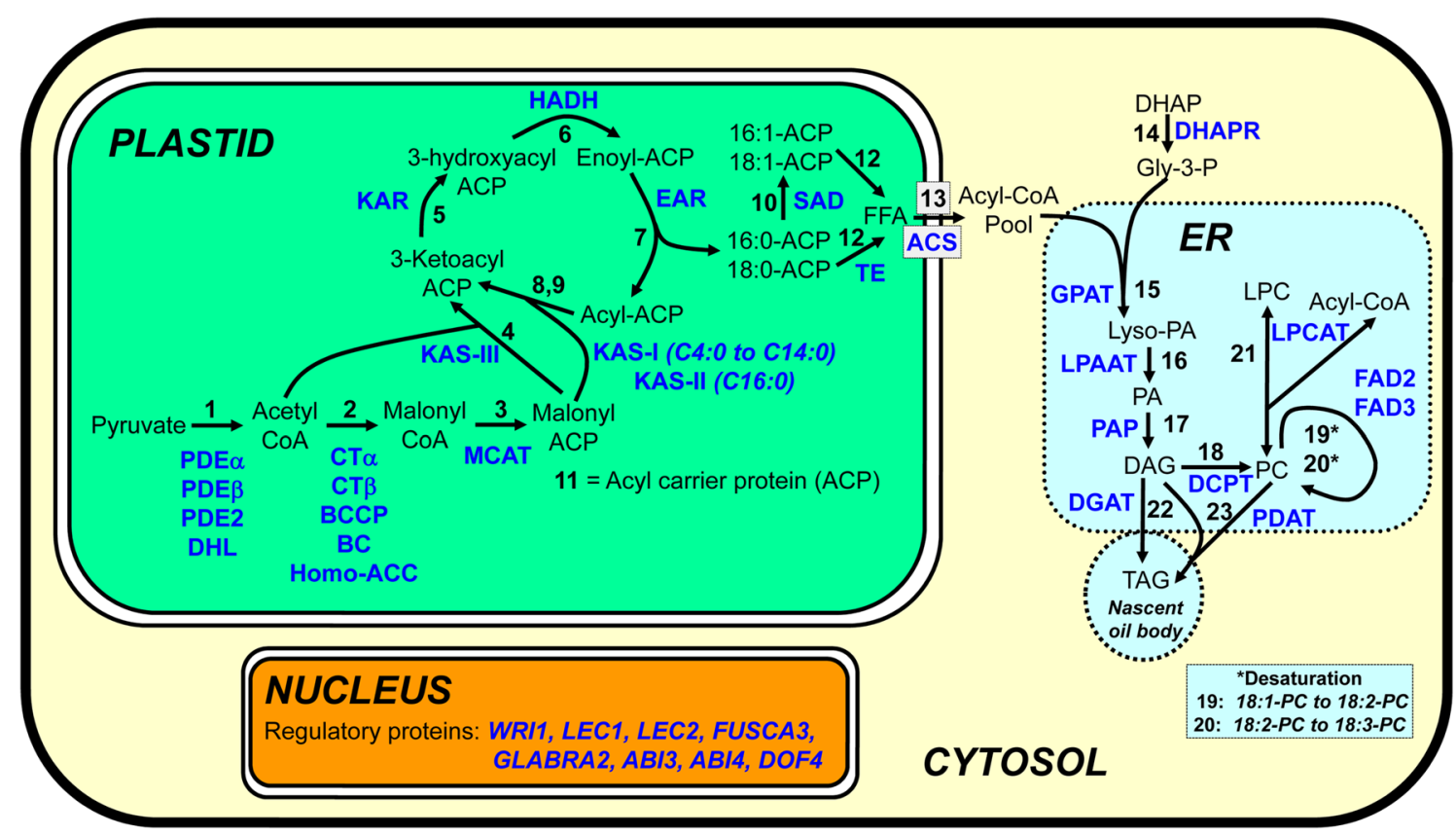

Fig. 3 Summary of mapped candidate genes involved in the biosynthesis of storage lipids in J. curcas. The genes, indicated in blue text, are as follows: Plastid-(1) PDE $\alpha \alpha$-subunit of the pyruvate dehydrogenase (PDH) complex, PDE $\beta \beta$-subunit of the PDH complex, PDE2 dihydrolipoyl transacetylase component of the PDH complex and PDE3 dihydrolipoamide dehydrogenase component of the PDH complex; (2) CT $\alpha$-subunit of the heteromeric acetyl-coA carboxylase (ACCase) complex, CT $\beta \beta$-subunit of the heteromeric ACCase complex, BCCP biotin carboxyl carrier protein and $B C$ biotin-carboxylase subunit of the heteromeric ACCase complex; (3) MCAT malonyl-CoA:ACP malonyltransferase (4,8 and 9) and KAS 3-ketoacylACP synthase; (5) KAR 3-ketoacyl-ACP reductase; (6) HADH 3-hydroxylacyl-ACP dehydratase; (7) EAR enoyl-ACP reductase; (10) SAR stearoyl-ACP reductase; (11) ACP acyl carrier protein; (12) ACP-TE acyl-ACP thioesterase; (13) ACS acyl-CoA synthetase. Cytosol-(14) DHAPR dihydroxyacetone phosphate reductase. Endoplasmic Reticulum (ER)—(15) GPAT glycerol-3-phosphate acyltransferase; (16) LPAAT lysophosphatidic acid acyltransferase; (17) PAP phosphatidate phosphatase; (18) DCPT diacylglycerol:choline phosphatidyltransferase; (19, 20) FAD fatty acid desaturase; (21) LPCAT 1-acylglycerol-3-phosphocholine acyltransferase; (22) DGAT diacylglycerol acyltransferase; (23) PDAT phospholipid:diacylglycerol acyltransferase. Nucleus - regulatory proteins including Wrinkled1 (WR/1), Leafy Cotyledon 1 \& 2 (LEC1 \& LEC2), FUSCA3, GLABRA2, Abscisic Acid Insensitive 3 \& 4 (ABI3 $\& A B / 4)$ and DOF4. Abbreviations used for pathway intermediates (black) include DHAP dihydroxyacetone phosphatase, Gly-3-P glycerol-3-phosphate, Lyso-PA lysophosphatidic acid, PA phosphatidic acid, DAG diacylglycerol, TAG triacylglycerol, PC phosphatidylcholine and $L P C$ lysophosphatidylcholine 
Both vegetative traits and seed weight contribute to the oil yield in mapping population $\mathrm{G} 51 \times \mathrm{CV}$

The $\mathrm{F}_{2}$ mapping population $\mathrm{G} 51 \times \mathrm{CV}$, which has one "wild" partially heterozygous parent (G51, heterozygous at $46 \%$ of markers) and a fully homozygous "Cape Verde"-like parent, was created primarily for the identification of seed oil content QTL, based on contrasting phenotypes we observed for the parents of these plants (36.9 \% oil in G51, $26.0 \%$ oil in CV). However, we also collected data for various other traits in the field including plant height, stem diameter, canopy area, number of branches and number of seeds produced (see "Methods"). Normal, or near-normal distributions were observed for the majority of these traits (Additional file 4: Figure S1). To determine the relationship between these variables and the final calculated oil yields per plant, Pearson correlation coefficients were calculated (Table 2). For the final calculated oil yields, almost all of the traits produced significant positive correlations. Within the vegetative traits for example, the number of branches at 763 days $(R=0.474)$ and canopy area at 763 days $(R=0.431)$ produced the highest correlations for year 3 calculated oil yields. These correlations were very similar to those observed for total seeds per plant in year $3(R=0.457$ and 0.446$)$, suggesting that the yield correlations are most closely linked to a higher number of seeds produced in plants showing stronger vegetative growth. Unsurprisingly, the total number of seeds produced per plant was the most significant contributor to the final seed yield $(R=0.972$ and $R=0.948$ for years 2 and 3), indicating that for mapping population $\mathrm{G} 51 \times \mathrm{CV}$, the number of seeds per plant is more important than the amount of oil per seed. Nonetheless, 100-seed weights also produced significant correlations with the calculated oil yields $(R=0.205$ to $R=0.489$ ), as did seed oil content in the first harvest for year $3(R=0.402)$. Interestingly, for the year 3 data, the total number of seeds per plant also produced a weak but positive correlation with 100 -seed weights, indicating that the plants producing more seed do not appear to allocate fewer resources to each seed. Similarly, oil content and seed number either had no correlation or a weak positive correlation $(R=0.190$ for total seeds in year 3 and oil content in year 3 , harvest 1 ), showing producing more seeds does not reduce the amount of oil stored in the seed.

Overall, the data for this mapping population indicate that the final oil yield is a composite trait, and that the vigour of the plants contributes most significantly to oil yield by producing plants with increased number of seeds. However, 100-seed weights and oil content can also make significant contributions to final oil yield. This suggests that there should be significant potential for developing improved varieties of $J$. curcas through the pyramiding of desirable loci.

\section{Identification of QTL associated with vegetative growth characteristics, in mapping population G51 x CV}

After performing QTL analyses on the data collected from mapping population $\mathrm{G} 51 \times \mathrm{CV}$, we detected a number of QTL underlying vegetative traits (Table 3; Fig. 4; Additional file 5: Figure S2a-e and Additional file 6: Figure S3a-h). QTL for plant height were observed on both linkage group 4 and linkage group 8 (Table 3). The QTL on linkage group 4 was observed at both 567 and 763 days after transplantation from the nursery, accounting for 9.2 and $7.0 \%$ of the phenotypic variance explained (PVE) for these traits, respectively. The height QTL on linkage group 8 was only observed at 763 days, and also accounted for $7.0 \%$ PVE. Both of these QTL were minor and only detected using a significance threshold of $p=0.10$. The small effects of these height QTL are most likely related to the high level of complexity of this trait. Interestingly, ANOVA analysis of the phenotypes at the height QTL locus on linkage group 4 indicated that this QTL was overdominant, i.e. the heterozygous phenotype was greater than either of the homozygous phenotypes. At the same position of linkage group 4 as the height QTL, we also observed an overdominant QTL corresponding to stem diameter. This accounted for 14.9 and $8.9 \%$ PVE at 567 and 763 days, respectively. A further stem diameter QTL was detected on linkage group 5 at 567 days and linkage group 7 at 763 days. The QTL on linkage group 7 was the largest of these, accounting for $10.2 \%$ PVE. A single dominant QTL for branching was observed on linkage group 1 , for which the CV allele had a positive effect. We were unable to detect significant QTL for canopy area, perhaps due to the high level of complexity of the trait. Given the significances of the correlations between the plant vegetative growth traits and the calculated seed and oil yields obtained from the Pearson correlation analysis, the QTL on linkage group 4 for height and stem diameter would be useful targets in a plant breeding programme. The close proximity of these QTL and their similar overdominance indicates that this may be a single locus with a pleotropic effect. However, finer mapping would be required to determine whether these are the same or separate loci. Use of overdominant QTL in plant breeding would require the production of $F_{1}$ hybrid plants for implementation. Due to its monoecious, self-fertile nature, efficient production of $F_{1}$ hybrid seed would require an alternate strategy such as the cytoplasmic male sterility and restorer system [23]. Alternatively, $\mathrm{F}_{1}$ plants could be multiplied by vegetative propagation (i.e. from cuttings) or from micropropagation [24]. 
Table 3 Summary of QTL observed for vegetative and oil yield traits in the mapping population G51 x CV

\begin{tabular}{|c|c|c|c|c|c|c|c|c|c|c|}
\hline Trait & $\begin{array}{l}\text { Observa- } \\
\text { tions (n) }\end{array}$ & $\begin{array}{l}\text { Linkage } \\
\text { group }\end{array}$ & $\begin{array}{l}\text { Position } \\
\text { (cM) }\end{array}$ & $\operatorname{LOD}^{\mathrm{a}}$ & PVE & $\begin{array}{l}\text { Bayes } \\
95 \% \mathrm{Cl} \text { (cM) }\end{array}$ & $\begin{array}{l}\text { Beneficial } \\
\text { allele }\end{array}$ & Effect $^{\mathbf{b}}$ & $\begin{array}{l}\text { QTL plot } \\
\text { Additional } \\
\text { file 5: }\end{array}$ & $\begin{array}{l}\text { Effect plot } \\
\text { Additional } \\
\text { file 6: }\end{array}$ \\
\hline $\begin{array}{l}\text { Height } \\
\text { (567 days) }\end{array}$ & 144 & 4 & 7.05 (G37) & $3.03^{*}$ & 9.2 & $1.0-13.0$ & Heterozygous & OD & Fig. S2a & Fig. S3a \\
\hline \multirow{2}{*}{$\begin{array}{l}\text { Height } \\
\text { (763 days) }\end{array}$} & \multirow[t]{2}{*}{143} & 4 & 8.0 & $3.19^{*}$ & 7.0 & $3.34-25.73$ & Heterozygous & OD & Fig. S2b & Fig. S3b \\
\hline & & 8 & 36.0 & $3.18^{*}$ & 7.0 & $0.0-53.0$ & G51 & Dom & & Fig. S3C \\
\hline \multirow{2}{*}{$\begin{array}{l}\text { Stem diameter } \\
\text { (567 days) }\end{array}$} & \multirow[t]{2}{*}{144} & 4 & 7.05 (G37) & $4.35^{* * *}$ & 14.9 & $5.0-11.21$ & Heterozygous & $\mathrm{OD}$ & Fig. S2C & Fig. S3d \\
\hline & & 5 & 41.1 (G123) & $3.23^{*}$ & 8.5 & $26.0-44.02$ & CV & Dom & & Fig. S3e \\
\hline \multirow{2}{*}{$\begin{array}{l}\text { Stem diameter } \\
\text { (763 days) }\end{array}$} & \multirow[t]{2}{*}{143} & 7 & 13.0 & $4.31^{* * *}$ & 10.2 & $6.0-22.0$ & G51 & Dom & Fig. S2d & Fig. S3f \\
\hline & & 4 & 7.05 (G37) & $3.70^{* *}$ & 8.9 & $0.67-10.0$ & Heterozygous & $\mathrm{OD}$ & & Fig. S3g \\
\hline $\begin{array}{l}\text { Branching } \\
\text { (763 days) }\end{array}$ & 143 & 1 & 25.0 & $3.68^{* *}$ & 11.2 & $0.0-25.09$ & $C V$ & Dom & Fig. S2e & Fig. S3h \\
\hline $\begin{array}{l}\text { Total seeds, } \\
\text { year } 3\end{array}$ & 140 & 10 & 29.0 & $3.81^{* *}$ & 11.7 & $0.0-32.2$ & $C V$ & Dom & Fig. S2f & Fig. S3i \\
\hline \multirow{2}{*}{$\begin{array}{l}\text { Oil content, } \\
\text { year } 2\end{array}$} & \multirow[t]{2}{*}{142} & 4 & 32.0 & $4.73^{* * *}$ & 13.3 & $2.0-34.3$ & G51 & Dom & Fig. S2g & Fig. S3j \\
\hline & & 10 & 31.0 (JCT27) & $4.31^{* * *}$ & 12.1 & $4.0-32.2$ & G51 & Dom & & Fig. S3k \\
\hline $\begin{array}{l}\text { Oil content, } \\
\text { year 3a }\end{array}$ & 132 & 4 & 45.5 & $3.27^{* *}$ & 10.8 & $0.0-57.1$ & G51 & Dom & Fig. S2h & Fig. S31 \\
\hline $\begin{array}{l}\text { Oil content, year } \\
3 \mathrm{~b}\end{array}$ & 112 & 10 & 32.0 & $3.05^{*}$ & 11.8 & $1.0-32.2$ & G51 & Dom & Fig. S2i & Fig. S3m \\
\hline $\begin{array}{l}\text { 100-seed } \\
\text { weight, year } 2\end{array}$ & 142 & 4 & 7.05 (G37) & $7.90^{* * *}$ & 22.6 & $1.3-15.0$ & G51 & Dom & Fig. S2j & Fig. S3n \\
\hline $\begin{array}{l}\text { 100-seed } \\
\text { weight, year } \\
3 a\end{array}$ & 132 & 4 & $\begin{array}{l}1.34 \\
\quad(1407326 \mid \\
12327601)\end{array}$ & $5.04^{* * *}$ & 16.1 & $0.0-19.0$ & G51 & Dom & Fig. S2k & Fig. S3o \\
\hline $\begin{array}{l}\text { 100-seed } \\
\text { weight, year } \\
\text { 3b }\end{array}$ & 112 & 4 & 4.0 & $3.44^{* *}$ & 13.2 & $0.0-52$ & G51 & Dom & Fig. S2I & Fig. S3p \\
\hline
\end{tabular}

a The LOD significance thresholds are ${ }^{* * *} p=0.01,{ }^{* *} p=0.05$ or ${ }^{*} p=0.10$

${ }^{b}$ Effects are overdominant (OD), additive (Add) or dominant (Dom)

\section{Identification of QTL for seed number per plant, seed} weight and oil content in mapping population G51 $\times$ CV For the second harvest year after transplantation, although we observed a large variation in the number of seeds produced per plant (Additional file 4: Figure S1i), we did not observe any QTL associated with this trait. For the third harvest year, a single QTL was observed on linkage group 10, which accounted for an estimated $11.7 \%$ of the phenotypic variance (Table 3; Fig. 4). This QTL was dominant, with the CV allele being beneficial compared to the G51 allele. Interestingly, an oil content QTL was also observed at a similar position on linkage group 10 for the second harvest year and the second harvest of year 3, accounting for between 11.8 and $12.1 \%$ PVE. This QTL was dominant, with the beneficial allele being from the G51 parent (Additional file 6: Figures $\mathrm{S} 3 \mathrm{j}, \mathrm{m}$ ). Although this may suggest that there is a potential reduction in oil content in response to a higher level of seed production, it should be noted that no correlation was observed for seed number and oil content in the second harvest year, and the correlation was weak but positive in the third harvest year (Table 2). A further QTL for oil content was observed in the second harvest year on linkage group 4. This locus was dominant and accounted for $13.3 \%$ PVE. The beneficial allele was from the G51 parent. A QTL at a similar position was also identified for the first (but not second) harvest of year 3 $(\mathrm{PVE}=10.8 \%)$.

\section{QTL contributing to fatty acids composition of mapping population $\mathrm{G} 51 \times \mathrm{CV}$}

In $J$. curcas, the two main fatty acids present in the storage oil are oleate and linoleate. For biodiesel production, monounsaturated fatty acids such as oleate are regarded as being desirable, as they have greater oxidative stability than polyunsaturated fatty acids and do not have poor cold-flow and cloud-point characteristics associated with saturated fatty acids $[1,25,26]$. It has been shown previously that plant growth temperature is likely to play a significant role in the proportion of these two fatty acids [1]. Within this mapping population we also found a strong negative correlation in the percentage of oleate 


\section{Linkage Group 1

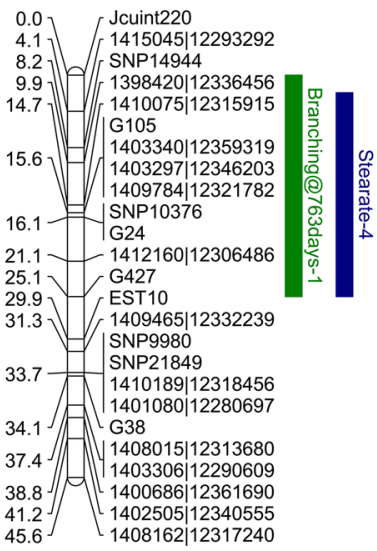

\section{Linkage Group 4}
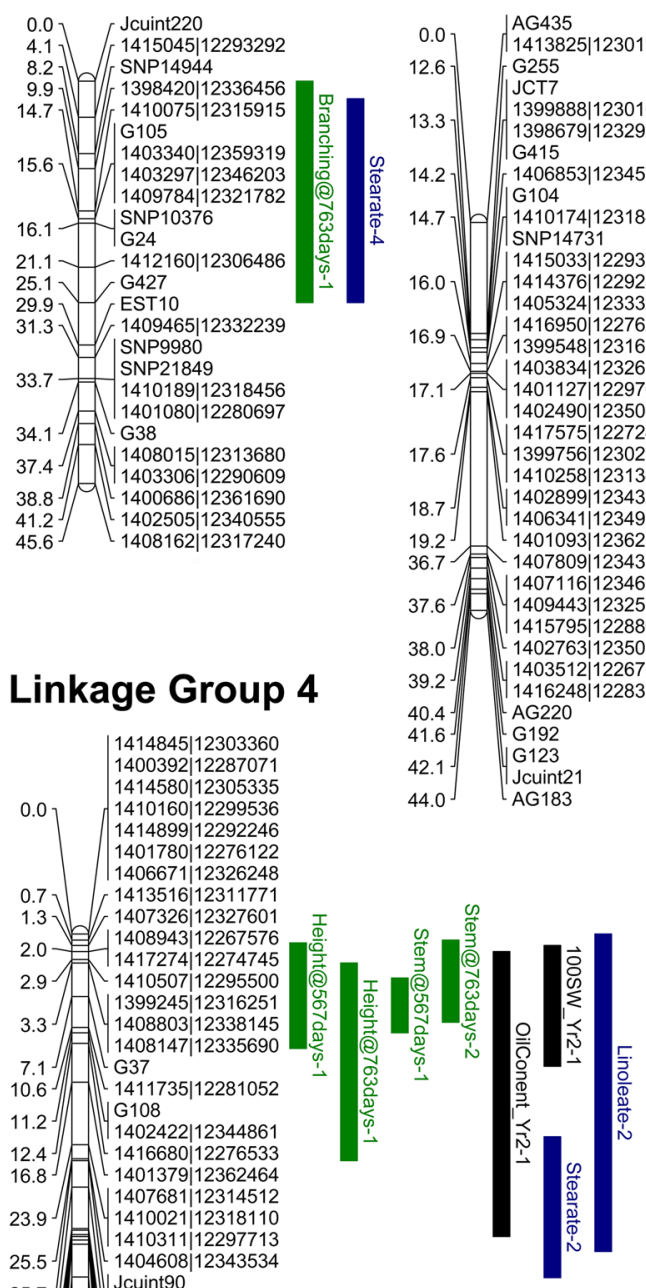

AG435

G 1455
GCT7
139988

G255
JCT7
13998881

G415

G104

SNP14731

AG220

192

(n)

G183

\section{Linkage Group 5}

AG435

1399888|12301012

1398679|12329288

$406853 \mid 12345796$

410174|12318426

$16.0] \quad \mid \quad \begin{aligned} & 1415033 \mid 12293274 \\ & 1414376 \mid 12292845\end{aligned}$

16.9 - $1416950 \mid 12276217$

目 $(1399548 \mid 12316523$

17.1 肙 $\mid \begin{aligned} & 1403834 \mid 12326123 \\ & 1401127 \mid 12297649\end{aligned}$

$17.1=\mid \begin{aligned} & 1401127 \mid 1229764 \\ & 1402490 \mid 1235067 \\ & 1417575 \mid 1227242\end{aligned}$

$\left.\begin{array}{l}17.6 \\ 18.7 \\ 19.2\end{array}\right] \mid\left[\begin{array}{l}1399756 \mid 12302951 \\ 1410258 \mid 12313412 \\ 1402899 \mid 12343285 \\ 1406341 \mid 12349947 \\ 1401093 \mid 12362750\end{array}\right.$

36.7 目 $1407809 \mid 12343704$

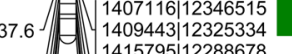

38.0 ] $\mid\left[\begin{array}{l}1415795 \mid 12288678 \\ 1402763 \mid 12350195 \\ 1403512 \mid 12267345\end{array}\right.$

$1403512 \mid 12267345$
$1416248 \mid 12283374$

25.7 ] || $\mid \begin{aligned} & \text { Jcuint90 } \\ & \text { JCT47 }\end{aligned}$

28.7 G407

$\left.\begin{array}{l|l|l}33.4 \\ 33.6\end{array}\right]$ G116

34.1

34.3 G357

34.7 - $1399779 \mid 12313258$

35.2 AG806

38.9 1406120|12346418

45.4 G376B

46.9 - $1409484 \mid 12332255$

49.0 G183

Fig. 4 Map of QTL detected in mapping population G51 × CV. QTL shown in green relate to vegetative traits (branching, stem diameter and plant height). QTL shown in black relate to seed yield traits (seeds per plant, 100-seed weight or oil content). QTL shown in blue relate to fatty acid composition in the seed oil (palmitate, stearate, oleate or linoleate). Only linkage groups found to contain QTL are shown

\section{Linkage Group 6 Linkage Group 8}

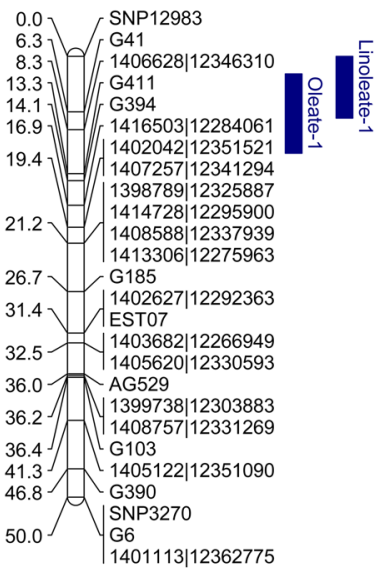

\section{Linkage Group 7}
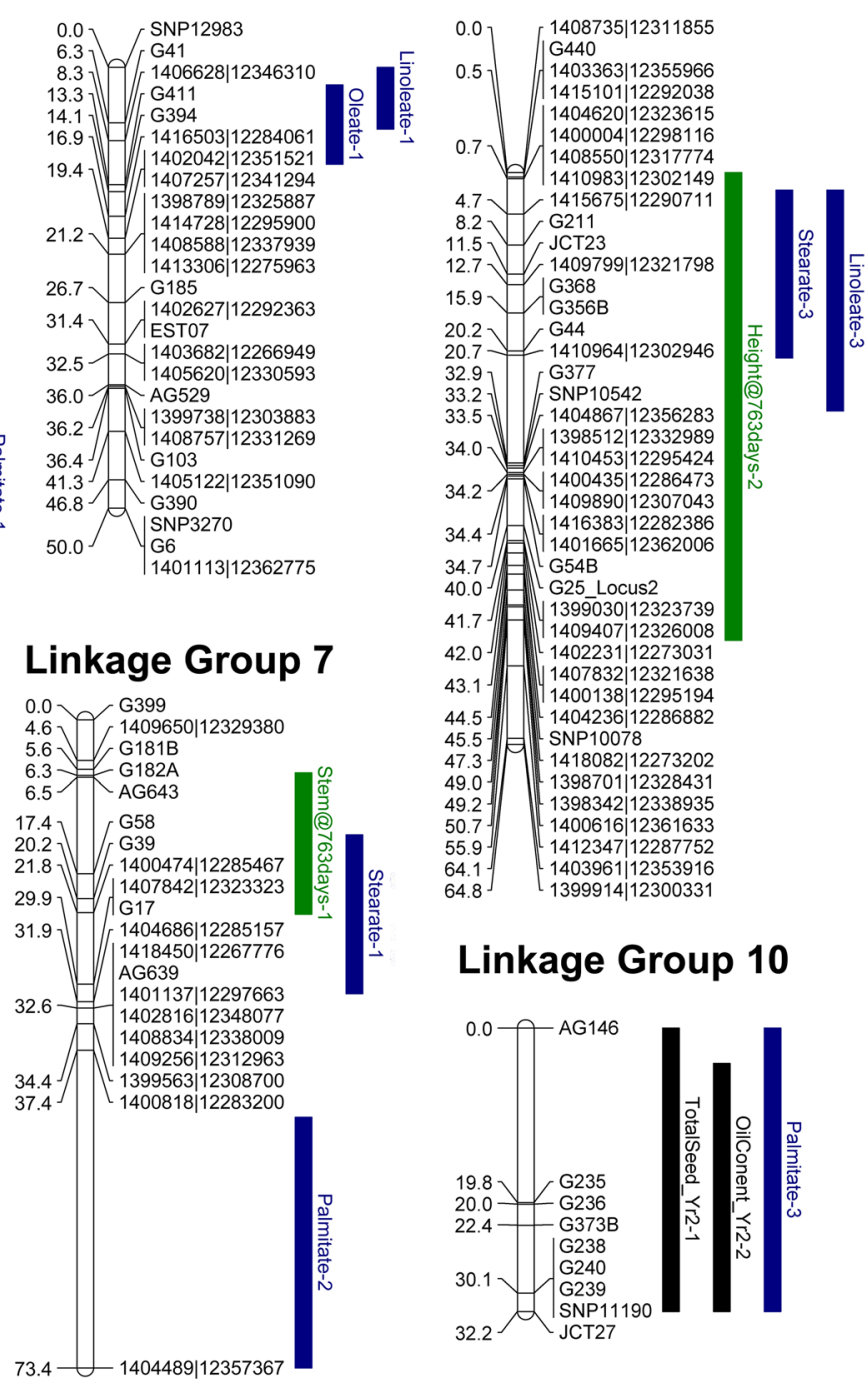

Linkage Group 10

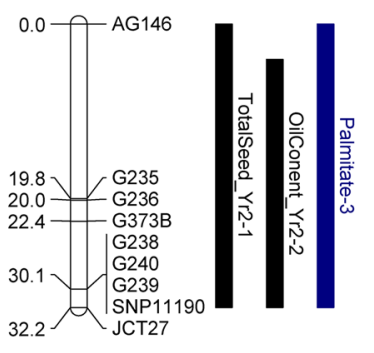

(42.6-50.5 \%) and linoleate (26.6-35.3\%) content within the seeds, suggesting that variation in these two fatty acids is both genetically and environmentally determined (Table 4 and Additional file 6: Figure S1). A number of QTL were observed for these two fatty acids (Table 5). On linkage group 6, a QTL was observed at 2 cM (10.8\% PVE) and 3 cM (11.9\% PVE), respectively, for oleate and linoleate content. Given the strong negative correlation between these two fatty acids, it is probable that the same underlying gene is responsible. Two additional QTL for linoleate content were observed on linkage groups 4 (at $4 \mathrm{cM}$ ) and 8 (at $11.5 \mathrm{cM}$ ), with PVE of 11.1 and $9.9 \%$, respectively.

The two other main fatty acids present in the seeds of J. curcas are palmitate $(10.7 \%-13.9 \%)$ and stearate (6.1$9.2 \%)$. Although the variations in stearate content were 
Table 4 Pearson correlation coefficients for oil content, 100-seed weight and fatty acid composition in the mapping population G51 x CV

\begin{tabular}{|c|c|c|c|c|c|}
\hline & 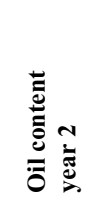 & 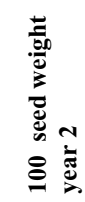 & 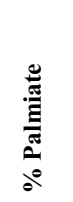 & 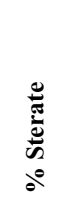 & 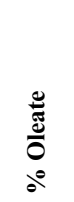 \\
\hline 100 seed weight & 0.434 & & & & \\
\hline$\%$ Palmitate & $\begin{array}{c}-0.166 \\
0.050\end{array}$ & $\begin{array}{l}0.180 \\
0.034\end{array}$ & & & \\
\hline$\%$ Stearate & $\begin{array}{r}-0.020 \\
0.813\end{array}$ & $\begin{array}{r}-0.136 \\
0.108\end{array}$ & $\begin{array}{r}-0.297 \\
0.000\end{array}$ & & \\
\hline$\%$ Oleate & $\begin{array}{r}-0.011 \\
0.895\end{array}$ & $\begin{array}{r}-0.187 \\
0.027\end{array}$ & $\begin{array}{l}-0.423 \\
0.000\end{array}$ & $\begin{array}{l}0.289 \\
0.001\end{array}$ & \\
\hline \% Linoleate & $\begin{array}{l}0.185 \\
0.028\end{array}$ & $\begin{array}{l}0.230 \\
0.006\end{array}$ & $\begin{array}{l}0.110 \\
0.197\end{array}$ & $\begin{array}{r}-0.499 \\
0.000\end{array}$ & $\begin{array}{r}-0.835 \\
0.000\end{array}$ \\
\hline
\end{tabular}

The upper uncoloured cells contain the $R$ values. The lower coloured cells contain the $p$ values. Cells shaded in green represent correlations with a $p$ value $<0.05$ and cells shaded in red represent a $p$ value $>0.05$. Details of data collection and calculation for each trait are provided in "Methods"

minor, four QTL were detected for stearate (Table 5), accounting in total for $45.7 \%$ PVE. One of these mapped to a similar position as the linoleate QTL on linkage group 8. Three QTL were observed for palmitate content, accounting for $28.3 \%$ PVE in total (Table 5).

\section{Identification of QTL for seed number per plant, seed} weight and oil content in mapping population G33 x G43 Mapping population G33 $\times$ G43 was originally developed for the purpose of identifying a locus responsible for the biosynthesis of phorbol esters [14], the principal toxin in J. curcas seeds. However, we were also able to identify a number of QTL for seed traits using this population (Table 6; Additional file 7: Figure S4, Additional File 8: Figure S5 and Additional file 9: Figure S6). Pearson correlation analysis of the trait data (Table 7) revealed that for all 3 years, the calculated oil yields were mainly dependent on the number of seeds produced per plant $(R \geq 0.98$ for all 3 years). Weak, but significant correlations were observed for oil content and oil yields in years 1 and 3 ( $R=0.333$ and 0.123 , respectively), but not in year 2 . Interestingly, weak but significant correlations between 100 -seed weight and oil yield were observed for all three years, but these were positive in year $1(R=0.203)$ and year $2(R=0.316)$ but negative in year $3(R=-0.142)$. Similarly, a negative correlation was observed between the 100 -seed weight and number of seeds produced per plant during year $3(R=-0.273)$. This may indicate that in the third year for this mapping population, source strength rather than sink capacity is important (i.e. as the plants produce more seeds, they are able to allocate fewer resources per seed), or that there is greater competition between individual plants of the mapping population for light or nutrients as the size of the plants increase.

For the first year we did not detect any QTL relating to the number of seeds per plant. For the number of seeds produced per plant during the second year, a weak QTL was observed $(p<0.10)$ when non-parametric analysis was performed. It should be noted, however, that the average number of seeds harvested per plant declined between years 1 and 2, due to adverse weather conditions at the field site of the G33 × G43 mapping population (see "Methods" and Additional file 7: Figures S4a, f). In the year 3, we observed that two QTL were found on linkage groups 4 and 7 , accounting for $11.3 \%$ PVE.

Table 5 Summary of QTL observed for fatty acid composition mapping population G51 x CV

\begin{tabular}{|c|c|c|c|c|c|c|c|c|c|c|c|}
\hline Trait & $\begin{array}{l}\text { Observa- } \\
\text { tions (n) }\end{array}$ & Method & $\begin{array}{l}\text { Linkage } \\
\text { group }\end{array}$ & $\begin{array}{l}\text { Position } \\
\text { (cM) }\end{array}$ & $\operatorname{LOD}^{a}$ & PVE & $\begin{array}{l}\text { Bayes } 95 \% \\
\mathrm{Cl}(\mathrm{cM})\end{array}$ & $\begin{array}{l}\text { "High" } \\
\text { genotype }\end{array}$ & Effect $^{b}$ & $\begin{array}{l}\text { QTL plot } \\
\text { Additional } \\
\text { file 5: }\end{array}$ & $\begin{array}{l}\text { Effect plot } \\
\text { Additional } \\
\text { file } 6:\end{array}$ \\
\hline \multirow[t]{3}{*}{$\%$ Palmitate } & 140 & HK & 5 & 28.0 & $5.48^{* * *}$ & 13.2 & $19.2-41.6$ & $\mathrm{CV}$ & Add & Fig. S2m & Fig. S3q \\
\hline & & HK & 7 & 58.0 & $3.36^{* *}$ & 7.8 & $45.0-73.5$ & $C V$ & Rec & & Fig. S3r \\
\hline & & HK & 10 & 32.0 & $3.12^{*}$ & 7.3 & $0.0-32.2$ & Heterozygous & OD & & Fig. S3s \\
\hline \multirow[t]{4}{*}{$\%$ Stearate } & 140 & $H K$ & 7 & 25.0 & $8.34^{* * *}$ & 16.1 & $13.0-31.0$ & G51 & Add & Fig. S2n & Fig. S3t \\
\hline & & HK & 4 & 27.0 & $6.01^{* * *}$ & 12.3 & $23.0-39.0$ & $\mathrm{CV}$ & Add & & Fig. S3u \\
\hline & & HK & 8 & 11.0 & $5.34^{* * *}$ & 10.9 & $2.0-21.0$ & G51 & Dom & & Fig. S3v \\
\hline & & HK & 1 & $\begin{array}{r}9.9(1398420 \\
\mid 12336456)\end{array}$ & $3.57^{* *}$ & 6.4 & $2.0-25.1$ & G51 & Dom & & Fig. S3w \\
\hline$\%$ Oleate & 140 & HK & 6 & 2.0 & $3.47^{* *}$ & 10.8 & $2.0-11.0$ & $\mathrm{CV}>\mathrm{G} 51>\mathrm{Het}$ & -ve, OD & Fig. S2O & Fig. S3x \\
\hline \multirow[t]{3}{*}{$\%$ Linoleate } & 140 & $H K$ & 6 & 3.0 & 5.05 & 11.9 & $0.0-7.0$ & G51 & Dom & Fig. S2p & Fig. S3y \\
\hline & & HK & 4 & 4.0 & 4.75 & 11.1 & $0.0-36.0$ & G51 & Dom & & Fig. S3z \\
\hline & & HK & 8 & 11.5 (JCT23) & 4.26 & 9.9 & $2.0-27.0$ & $\mathrm{CV}$ & Dom & & Fig. S3aa \\
\hline
\end{tabular}

\footnotetext{
a The LOD significance thresholds are ${ }^{* *} p=0.01,{ }^{* *} p=0.05$ or ${ }^{*} p=0.10$
}

b Effects are overdominant (OD), additive (Add) or dominant (Dom) 


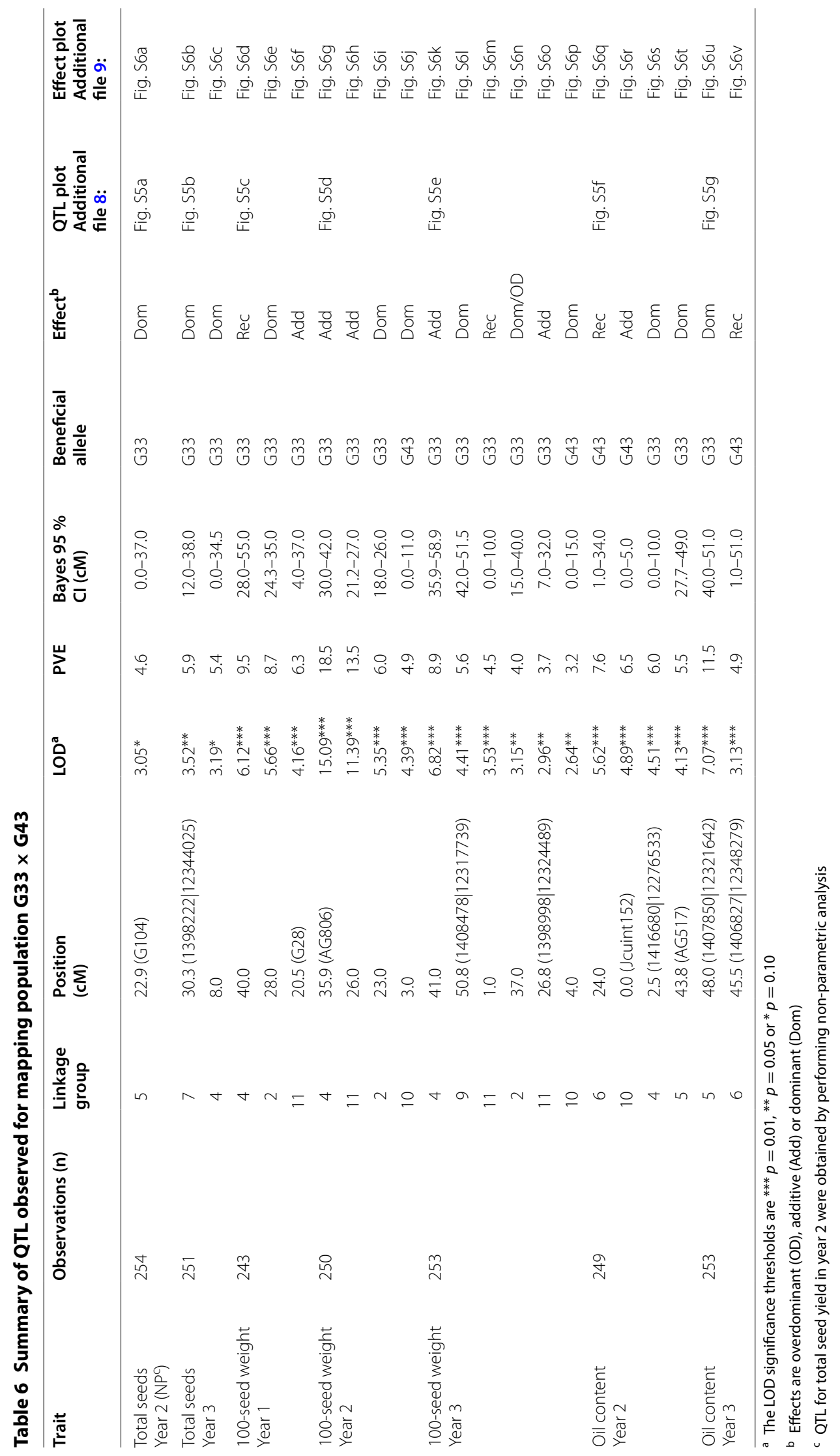


Table 7 Pearson correlation coefficients for seed traits in mapping population G33 x G43

\begin{tabular}{|c|c|c|c|c|c|c|c|c|c|c|c|c|c|c|}
\hline & 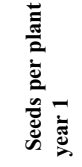 & 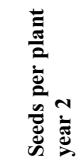 & 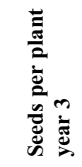 & 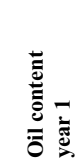 & 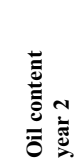 & 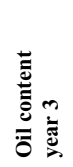 & 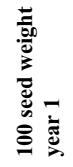 & 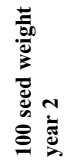 & 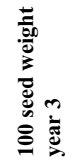 & 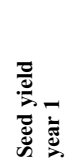 & 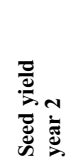 & 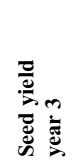 & $\begin{array}{l}\frac{}{0} \\
\frac{\pi}{3} \\
\overline{0}\end{array}$ & 苞 \\
\hline $\begin{array}{r}\text { Seeds per plant } \\
\text { year } 2\end{array}$ & & & & & & & & & & & & & & \\
\hline $\begin{array}{r}\text { Seeds per plant } \\
\text { year } 3\end{array}$ & $\begin{array}{l}0.223 \\
0.000\end{array}$ & $\begin{array}{l}0.185 \\
0.003\end{array}$ & & & & & & & & & & & & \\
\hline $\begin{array}{r}\text { Oil content } \\
\text { year } 1 \\
\end{array}$ & $\begin{array}{l}0.187 \\
0.004 \\
\end{array}$ & $\begin{array}{l}0.144 \\
0.025 \\
\end{array}$ & $\begin{array}{r}-0.013 \\
0.836 \\
\end{array}$ & & & & & & & & & & & \\
\hline $\begin{array}{r}\text { Oil content } \\
\text { year } 2 \\
\end{array}$ & $\begin{array}{r}-0.209 \\
0.001 \\
\end{array}$ & $\begin{array}{c}-0.109 \\
0.086\end{array}$ & $\begin{array}{l}0.043 \\
0.507 \\
\end{array}$ & $\begin{array}{l}0.288 \\
0.000\end{array}$ & & & & & & & & & & \\
\hline $\begin{array}{r}\text { Oil content } \\
\text { year } 3\end{array}$ & $\begin{array}{c}-0.019 \\
0.759\end{array}$ & $\begin{array}{l}0.014 \\
0.820\end{array}$ & $\begin{array}{l}0.058 \\
0.360 \\
\end{array}$ & $\begin{array}{l}0.264 \\
0.000 \\
\end{array}$ & $\begin{array}{l}0.485 \\
0.000\end{array}$ & & & & & & & & & \\
\hline $\begin{array}{r}100 \text { seed weight } \\
\text { year } 1\end{array}$ & $\begin{array}{c}-0.008 \\
0.900 \\
\end{array}$ & $\begin{array}{l}0.051 \\
0.443 \\
\end{array}$ & $\begin{array}{l}0.040 \\
0.543 \\
\end{array}$ & $\begin{array}{l}0.255 \\
0.000 \\
\end{array}$ & $\begin{array}{l}0.009 \\
0.885 \\
\end{array}$ & $\begin{array}{r}-0.034 \\
0.602 \\
\end{array}$ & & & & & & & & \\
\hline $\begin{array}{r}100 \text { seed weight } \\
\text { year } 2\end{array}$ & $\begin{array}{l}0.149 \\
0.019 \\
\end{array}$ & $\begin{array}{l}0.171 \\
0.007\end{array}$ & $\begin{array}{l}0.100 \\
0.119 \\
\end{array}$ & $\begin{array}{l}0.059 \\
0.370 \\
\end{array}$ & $\begin{array}{l}0.254 \\
0.000\end{array}$ & $\begin{array}{l}0.018 \\
0.773 \\
\end{array}$ & $\begin{array}{l}0.528 \\
0.000\end{array}$ & & & & & & & \\
\hline $\begin{array}{r}100 \text { seed weight } \\
\text { year } 3\end{array}$ & $\begin{array}{l}0.177 \\
0.005 \\
\end{array}$ & $\begin{array}{l}0.201 \\
0.001 \\
\end{array}$ & $\begin{array}{r}-0.273 \\
0.000 \\
\end{array}$ & $\begin{array}{l}0.080 \\
0.216 \\
\end{array}$ & $\begin{array}{r}-0.017 \\
0.786 \\
\end{array}$ & $\begin{array}{l}0.056 \\
0.373 \\
\end{array}$ & $\begin{array}{l}0.382 \\
0.000\end{array}$ & $\begin{array}{l}0.632 \\
0.000 \\
\end{array}$ & & & & & & \\
\hline $\begin{array}{r}\text { Seed yield } \\
\text { year } 1 \\
\end{array}$ & $\begin{array}{l}0.976 \\
0.000\end{array}$ & $\begin{array}{l}0.593 \\
0.000 \\
\end{array}$ & $\begin{array}{l}0.225 \\
0.000 \\
\end{array}$ & $\begin{array}{l}0.228 \\
0.000 \\
\end{array}$ & $\begin{array}{c}-0.216 \\
0.001 \\
\end{array}$ & $\begin{array}{r}-0.023 \\
0.721 \\
\end{array}$ & $\begin{array}{l}0.185 \\
0.004\end{array}$ & $\begin{array}{l}0.237 \\
0.000 \\
\end{array}$ & $\begin{array}{l}0.245 \\
0.000 \\
\end{array}$ & & & & & \\
\hline $\begin{array}{r}\text { Seed yield } \\
\text { year } 2 \\
\end{array}$ & $\begin{array}{l}0.577 \\
0.000\end{array}$ & $\begin{array}{l}0.988 \\
0.000 \\
\end{array}$ & $\begin{array}{l}0.187 \\
0.003 \\
\end{array}$ & $\begin{array}{l}0.138 \\
0.034\end{array}$ & $\begin{array}{r}-0.073 \\
0.249 \\
\end{array}$ & $\begin{array}{l}0.015 \\
0.819 \\
\end{array}$ & $\begin{array}{l}0.114 \\
0.080\end{array}$ & $\begin{array}{l}0.299 \\
0.000\end{array}$ & $\begin{array}{l}0.265 \\
0.000 \\
\end{array}$ & $\begin{array}{l}0.586 \\
0.000\end{array}$ & & & & \\
\hline $\begin{array}{r}\text { Seed yield } \\
\text { year } 3\end{array}$ & $\begin{array}{l}0.250 \\
0.000\end{array}$ & $\begin{array}{l}0.223 \\
0.000\end{array}$ & $\begin{array}{l}0.998 \\
0.000\end{array}$ & $\begin{array}{r}-0.001 \\
0.986\end{array}$ & $\begin{array}{l}0.035 \\
0.591\end{array}$ & $\begin{array}{l}0.065 \\
0.305\end{array}$ & $\begin{array}{l}0.088 \\
0.179\end{array}$ & $\begin{array}{l}0.185 \\
0.004\end{array}$ & $\begin{array}{r}-0.144 \\
0.016\end{array}$ & $\begin{array}{l}0.261 \\
0.000\end{array}$ & $\begin{array}{l}0.236 \\
0.000\end{array}$ & & & \\
\hline $\begin{array}{r}\text { Oil yield } \\
\text { year } 1\end{array}$ & $\begin{array}{l}0.993 \\
0.000\end{array}$ & $\begin{array}{l}0.589 \\
0.000\end{array}$ & $\begin{array}{l}0.215 \\
0.001\end{array}$ & $\begin{array}{l}0.333 \\
0.000\end{array}$ & $\begin{array}{r}-0.172 \\
0.008\end{array}$ & $\begin{array}{l}0.013 \\
0.838\end{array}$ & $\begin{array}{l}0.203 \\
0.002\end{array}$ & $\begin{array}{l}0.231 \\
0.000\end{array}$ & $\begin{array}{l}0.244 \\
0.000\end{array}$ & $\begin{array}{l}0.992 \\
0.000\end{array}$ & $\begin{array}{l}0.582 \\
0.000\end{array}$ & $\begin{array}{l}0.245 \\
0.000\end{array}$ & & \\
\hline $\begin{array}{r}\text { Oil yield } \\
\text { year } 2\end{array}$ & $\begin{array}{l}0.556 \\
0.000\end{array}$ & $\begin{array}{l}0.979 \\
0.000\end{array}$ & $\begin{array}{l}0.189 \\
0.003\end{array}$ & $\begin{array}{l}0.165 \\
0.011\end{array}$ & $\begin{array}{l}0.007 \\
0.915\end{array}$ & $\begin{array}{l}0.057 \\
0.376\end{array}$ & $\begin{array}{l}0.124 \\
0.057\end{array}$ & $\begin{array}{l}0.316 \\
0.000\end{array}$ & $\begin{array}{l}0.269 \\
0.000\end{array}$ & $\begin{array}{l}0.567 \\
0.000\end{array}$ & $\begin{array}{l}0.996 \\
0.000\end{array}$ & $\begin{array}{l}0.199 \\
0.002\end{array}$ & $\begin{array}{l}0.568 \\
0.000\end{array}$ & \\
\hline $\begin{array}{r}\text { Oil yield } \\
\text { year } 3\end{array}$ & $\begin{array}{l}0.244 \\
0.000\end{array}$ & $\begin{array}{l}0.222 \\
0.000\end{array}$ & $\begin{array}{l}0.986 \\
0.000\end{array}$ & $\begin{array}{l}0.011 \\
0.872\end{array}$ & $\begin{array}{l}0.067 \\
0.300\end{array}$ & $\begin{array}{l}0.123 \\
0.053\end{array}$ & $\begin{array}{l}0.082 \\
0.208\end{array}$ & $\begin{array}{l}0.185 \\
0.004\end{array}$ & $\begin{array}{r}-0.142 \\
0.025\end{array}$ & $\begin{array}{l}0.252 \\
0.000\end{array}$ & $\begin{array}{l}0.235 \\
0.000\end{array}$ & $\begin{array}{l}0.998 \\
0.000\end{array}$ & $\begin{array}{l}0.245 \\
0.000\end{array}$ & $\begin{array}{l}0.240 \\
0.000\end{array}$ \\
\hline
\end{tabular}

The upper uncoloured cells contain the $R$ values. The lower coloured cells contain the $p$ values. Cells shaded in green represent correlations with a $p$ value $<0.05$, cells shaded in yellow represent a $p$ value of between 0.05 and 0.10 , whereas cells shaded in red represent a $p$ value $>0.10$ (non-significant). Details of data collection and calculation for each trait are provided in "Methods"

The largest QTL detected for this population were for the 100-seed weights. In the first harvest year, three QTL were detected on linkage groups 2, 4 and 11, which accounted from $24.5 \%$ PVE. In the second harvest year, three QTL at similar positions were also identified, alongside an additional QTL on linkage group 10. In total, these accounted for $42.9 \%$ PVE. In the third year, six QTL for 100-seed weight were observed, although the total PVE declined to $29.9 \%$. The two additional QTL were on linkage group 9 and the upper arm of linkage group 11. The QTL on linkage groups 4 and in the middle of linkage group 11 were additive, whereas those on linkage groups 2, 9 and 10 were dominant. The QTL on the upper arm of linkage group 11 (year 3 only) was recessive. With the exception of the QTL on linkage group 10, the allele from the G33 parent was beneficial in each case. Based on the confidence intervals, it does not appear that the QTL on linkage group 4 of this mapping population is co-located with the 100-seed weight QTL we observed in mapping population G51 $\times \mathrm{CV}$. For the second harvest year, four QTL accounting for a total of $25.6 \%$ PVE were detected from seed oil content, on linkage groups 4 , 5, 6 and 10. In the subsequent year, we only observed the QTL on linkage groups 5 and 6, which had a total PVE of $16.4 \%$. The beneficial allele for the QTL on linkage groups 4 and 5 was from patent G33, whereas the beneficial allele for the other two QTL (linkage groups 6 and 10) were from parent G43. Two of these QTL, on linkage groups 4 and 10, may be related to the oil QTL observed in mapping population $\mathrm{G} 51 \times \mathrm{CV}$, though due to the relatively large QTL intervals compared to those observed in the G33 $\times$ G43 population, this would require further experimental confirmation. Interestingly, the oil content QTL on linkage group 10 also maps to a similar position as the seed weight QTL on this linkage group and in both instances, the G43 parent contributed the beneficial allele.

\section{Comparison of QTL positions with mapped candidate genes for lipid biosynthesis}

Where the position of candidate genes are known, it is possible to compare QTL positions to determine whether they may potentially underlie a specific QTL. This approach is most effective when the confidence intervals for the QTL are low. Based on our successful mapping of the majority of the candidate genes we identified involved in lipid biosynthesis (Fig. 3 and Additional file 3: Table S14), we compared the positions of these genes and QTL. In mapping population G51 $\times$ CV the majority of the QTL had very large $95 \%$ confidence intervals, but the 
main QTL for oleate and linoleate appeared to be located between 2.0 and 7.0 of linkage group 6 (Table 5 ).

A likely candidate gene for this QTL would be oleate desaturase (FAD2), an enzyme which converts an oleate group at the sn2-position of phospholipids to linoleate (Fig. 3, step 19). In J. curcas there are two FAD2 genes, both of which are expressed within developing seeds [27]. We mapped these to linkage groups 1 and 6 (Additional file 3: Table S3). The Bayes $95 \%$ confidence intervals for the QTL would indicate that it is unlikely that the FAD2 on linkage group 6 could be the locus underlying the main QTL for oleate. However, the $95 \%$ confidence intervals indicated that this QTL mapped between two markers (SNP12983 and 1406628|12346310) which both resided on a single $3.37 \mathrm{Mbp}$ scaffold (KK915213.1) of the $J$. curcas genome sequence released by the Chinese Academy of Sciences (Additional file 2: Table S8). This scaffold contains 560 predicted gene sequences, of which 134 are located within the $726 \mathrm{~kb}$ of sequence between these two markers. Further analysis of polymorphisms in this region should provide more insight into discovering the underlying genetic basis of the observed variation between oleate and linoleate content. The strongest QTL for stearate content on linkage group 7 mapped in close proximity to the genes for both acyl-ACP thioesterase (Step 12) and an acyl-CoA synthetase. The acyl-ACP thioesterase gene of linkage group 7 encodes the FatA type of enzyme (Additional file 2: Table S14), which typically displays a preference for oleoyl-ACP, whereas the FatB type typically show broader specificity including activity with saturated acyl-ACPs [28]. The long-chain acyl-CoA synthetases involved in activation of the export and activation of fatty acids from the plastids also show broad specificity [29]. Although the colocalization of these two genes with the stearate QTL is interesting from a biological perspective, given the relatively minor importance and the small amount of absolute variation in stearate content, we do not think this QTL warrants further investigation from a plant breeding perspective.

In the G33 $\times$ G43 mapping population, the QTL with the smallest interval was for oil content in the second harvest year. The Bayes $95 \%$ confidence interval for this QTL indicated that it resided within a $5 \mathrm{cM}$ interval on linkage group 10, between markers Jcuint152 and 1403415|12338032 (Additional file 2: Table S12). Both of these markers reside on a single $3.63 \mathrm{Mbp}$ scaffold (KK914240.1) which contains 394 genes. It should be noted, however, that in comparison to the composite interval map (Fig. 2), $5 \mathrm{cM}$ of the upper arm of the linkage group for mapping population G33 × G43 was not mapped and the QTL may have resided within this region. Interestingly, however, one of the candidate gene markers that mapped to scaffold KK914240.1 was for the $A B A$ Insensitive ( $A B I) 4$ gene. The $\mathrm{ABI}$ gene family includes abscisic acid (ABA)-responsive transcription factors which have roles in the regulation of a number of biochemical and developmental processes. In Arabidopsis, the ABI4 protein is known to be a regulator of DGAT1 expression in seedlings [30]. The role of ABI4 in oil accumulation during seed development is less clear, and ABI3 seems to play a more dominant role [31]. The role of ABI genes in Jatropha has not been studied extensively, but ABI4 expression has been shown to correlate with the stages of seed development in which oil accumulation occurs [32]. The oil content QTL on linkage group 5, which appeared in both years 2 and 3, produced relatively short confidence interval of $11 \mathrm{cM}$ (Table 6). Although this QTL interval could not be located to a single scaffold of the genome, analysis of the combined genetic/physical map (Additional file 2: Table S3) and the populationspecific map for G33 $\times$ G43 (Fig. 5) revealed that $9 \mathrm{cM}$ of this region corresponded to a single scaffold (GenBank KK914632.1, containing a predicted 133 genes). A pair of tandemly duplicated phosphatidate phosphatase (PAP) genes is located on this scaffold (Fig. 3, step 17 and Additional file 3: Table S14). The PAP enzyme is part of the ER pathway and converts phosphatidic acid into diacylglycerol. In Arabidopsis, a PAP gene was also shown to underlie a QTL for oil content in a mapping population segregating for this trait [33]. These two PAP genes in J. curcas therefore represent strong potential causal gene candidates responsible for the oil content QTL on linkage group 5. One further oil content QTL on linkage group 4 also had a relatively short confidence interval of $10 \mathrm{cM}$. Comparison of the marker positions (Fig. 5) with the mapped scaffolds indicated that this QTL is likely to reside on scaffold KK914227, which is $2.74 \mathrm{Mbp}$ and contains 274 predicted genes (Additional file 2: Table S6). Included within these genes was one of the mapped lipid biosynthesis genes, malonyl-CoA:ACP malonyl transferase (Fig. 3 and Additional file 3: Table S6). Our future work will involve characterization of these genes in the different parental populations, including upstream regions and gene expression levels, to determine whether there is any variation between the two parental lines.

\section{Future approaches to QTL mapping in J. curcas}

In addition to being able to identify a number of QTL, we were in some cases able to identify specific DNA scaffolds from the CAS Jatropha genome assemblies underlying these QTL and even identify candidate genes that may be responsible for these QTL. Nonetheless, in many instances, the QTL confidence intervals were too large to identify specific genome regions. The mapping resolution obtained by the family-based mapping approach is often limited as QTL intervals are usually dependent 


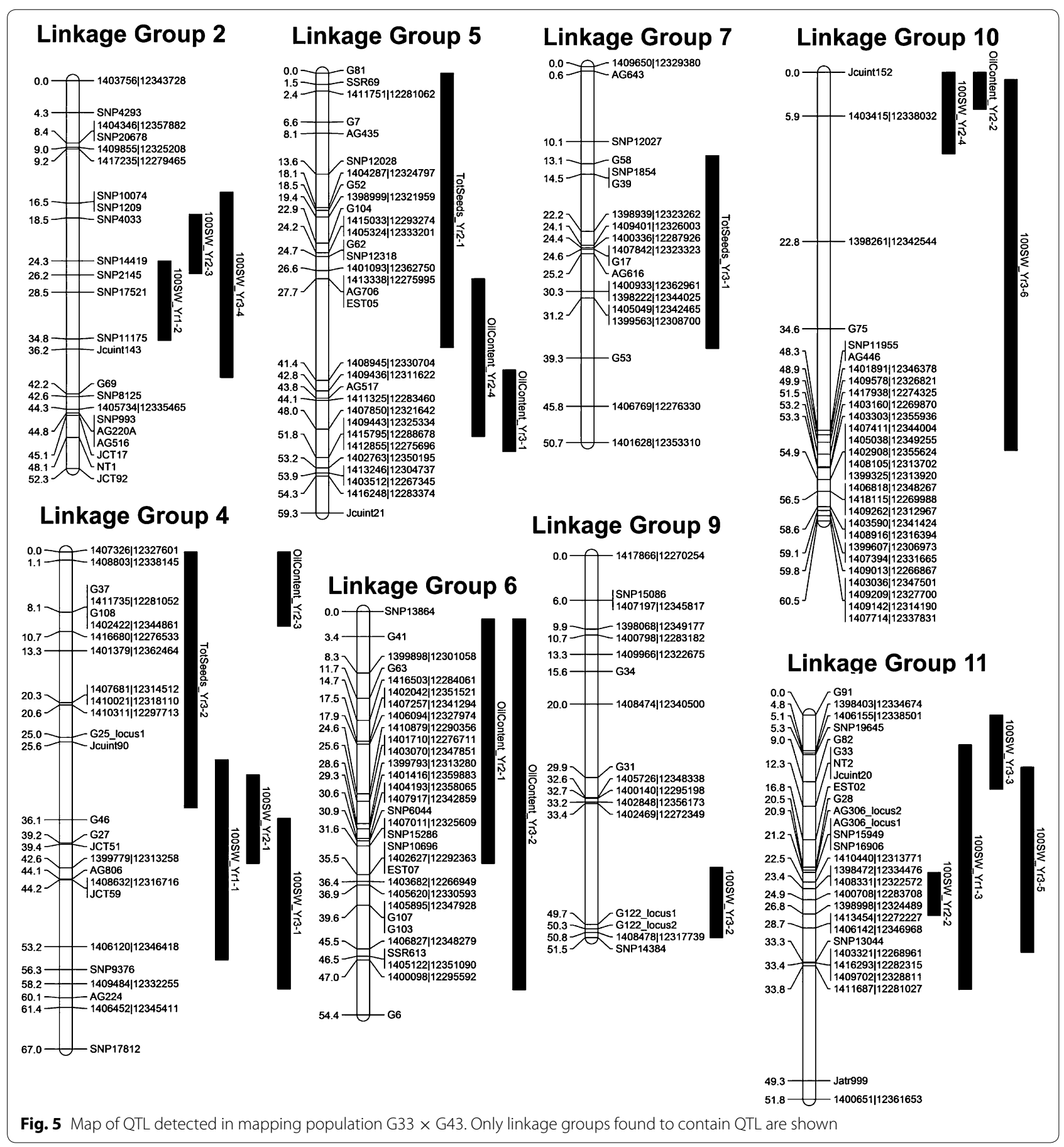

on population size, QTL effect and marker density [34]. Increasing the number of meioses within a mapping population by generating advanced-generation crosses can be used for finer mapping of QTL, but this approach is impractical with perennial plants because of the length of time required to produce and collect phenotypic data from each generation. An alternative approach that improves the ability to identify loci-controlling traits is a genome-wide association study (GWAS). This approach permits a higher resolution than family-based mapping by exploiting historical recombination events and does not therefore rely on the creation of experimental populations. The use of germplasm collections rather than biparental crosses also permits the identification 
of beneficial alleles from a wider genetic background. We believe that the advances that have been obtained by combined genetic and physical mapping that have been reported in the current study and elsewhere [18], together with the improvements in our knowledge of the availability of genetically diverse germplasm for this species within Mesoamerica [10, 12], make GWAS a feasible next step. In addition, it should also be possible to further improve and integrate the genetic and physical maps of J. curcas by developing molecular markers for unmapped scaffolds using an approach similar to the one we used previously to fine-map the phorbol ester biosynthesis locus in J. curcas [14]. These approaches should lead to the identification and characterization of a greater number of QTL from a wider genetic pool.

\section{Conclusions}

The identification of QTL for traits associated with oil yield in two mapping populations of J. curcas is a significant step forward in the development of improved commercial varieties of $J$. curcas. By stacking a number of these QTL, together with the locus we previously identified controlling phorbol ester biosynthesis [14], it should be possible to create higher-yielding non-toxic varieties suitable for the production of both vegetable oil and seed meal that can readily be converted into animal feed. The use of marker-assisted breeding is particularly beneficial for a large perennial plant such as J. curcas, as it allows selection of individuals containing multiple beneficial alleles prior to transplantation from nursery to the field. For QTL which are additive or dominant, the implementation of a breeding strategy would involve creating genetically stable (near homozygous) plants. Ordinarily, in plant breeding, the aim is to introgress one or more QTL into an "elite" cultivar and then remove non-target regions through successive backcrossing. Due to the present lack of such elite cultivars in J. curcas, it is instead likely that the approach adopted would require a combination of phenotypic and genotypic selection to ensure that new lines are both genetically stable and display superior performance compared to existing varieties, i.e. in the absence of any other supporting information, nonQTL regions could contain homozygous background from either parental plant.

One of the most interesting QTL to be identified from this study was a pleiotropic QTL on linkage group 4 which contributed to both plant height and stem diameter, both of which were shown to correlate positively with oil yield ( $R=0.306-0.396$, Additional file 2: Table S2). The fact that these QTL were overdominant indicates that heterosis (i.e. use of $F_{1}$ hybrids) may be an effective strategy in the development of new varieties of $J$. curcas. As discussed previously, implementation of this approach would require a method of producing $F_{1}$ plants on a large scale. Nonetheless, a further investigation into the potential of heterosis in J. curcas could be evaluated by first identifying or creating near-isogenic parental lines from the diverse germplasm that is found in Mesoamerica.

In summary, the QTL identified in this study provide a valuable starting point for the development of new cultivars of J. curcas. In conjunction with phenotypic selection, these markers can be used to create genetically stable cultivars containing multiple QTL that are likely to improve the overall yield of this important emerging oil crop.

\section{Methods \\ Mapping populations}

The two $\mathrm{F}_{2}$ mapping populations used for QTL analysis have been described previously [14]. Mapping population G51 × CV was grown at $\left(13^{\circ} 57^{\prime} 33.17^{\prime \prime} \mathrm{N}\right.$ and $\left.90^{\circ} 23^{\prime} 21.89^{\prime \prime} \mathrm{W}\right)$ and transferred from the nursery to the field on 25 May 2010. Mapping population G33 $\times$ G43 was grown at $\left(13^{\circ} 57^{\prime} 41.18^{\prime \prime} \mathrm{N}\right.$ and $\left.90^{\circ} 23^{\prime} 29.77^{\prime \prime} \mathrm{W}\right)$ and transferred from the nursery to the field on 23 July 2011. Both mapping populations were grown at a density of $4 \mathrm{~m}$ by $2 \mathrm{~m}$ (equivalent to 1250 plants per hectare). The transplantation of both populations was done during the rainy season in Guatemala (May-October). During the dry season (November-April), the plants were watered with a drip irrigation system. Fertilization was done through the irrigation system according to the nutritional requirements of the plant and soil analyses.

\section{Genotyping and linkage map construction}

The development of molecular markers and construction of genetic linkage maps for the populations used in this study have been described previously [14, 35]. Additional SSR markers were added to the map, either to fill in gaps or locate the position of specific candidate genes. The sequences of these SSR markers are provided in Additional file 1: Table S1. A list of markers linked to candidate genes involved in oil biosynthesis [27, 36] is provided in Additional file 3: Table S14.

\section{Collection of phenotypic data}

Plant heights, stem diameters, canopy diameters and the number of branches per plant were recorded at specific dates after transplantation as detailed in Table 1. For canopy areas, two measurements were taken: the first measurement was taken along the axis of the row ( 2 m plant spacing), whereas the second measurements were taken on the axis between rows ( $4 \mathrm{~m}$ plant spacing). These values were then used to calculate the canopy areas using the formula $\mathrm{CA}=\pi \times r 1 \times r 2$. The total number of seeds collected per harvest year was calculated from 
1 February to 31 January. Oil content and seed weights were determined using an Oxford Instruments MQC Benchtop NMR analyser (Abingdon, Oxfordshire) [37]. The machine was calibrated for oil content using preweighed samples of pure Jatropha oil in glass vials. For calibration of water content, samples of seeds which had been stored at ambient temperature and different relative humidities were used. For each plant, typically 48 seeds, but minimally 20 seeds, were used to determine the oil and moisture content. Oil contents and 100-seed weights were then calculated by adjusting the values for all samples to $7 \%$ water. Seed yields were calculated by multiplying the total number of seeds per plant by the 100 -seed weight $/ 100$. This oil yield was calculated by multiplying seed yield by the percentage oil content $/ 100$. To analyse fatty acid compositions, 24 seeds were ground to a fine powder using a domestic coffee grinder. A small aliquot (ca. $10 \mathrm{mg}$ ) of the ground seed was then converted to fatty acid methyl esters and analysed on a gas chromatograph equipped with a flame-ionization detector as described previously [38].

\section{QTL analyses}

After construction of the genetic maps, non-segregating markers were binned to form a single marker. Where possible, gaps in the map were filled using information from flanking markers. Finally, a number of markers which were only partially informative were removed. The resulting datasets are provided as Additional files 10 and 11. QTL analysis was performed using R/qtl [39]. An initial scan was performed using Haley-Knott regression [40]. LOD thresholds were determined using 10,000 permutations, and significance thresholds were set at $p=0.10, p=0.05$ and $p=0.01$. After the identification of the initial QTL, Haley-Knott regression analysis was performed using the makeqtl and addqtl functions. This process was repeated until no further QTL with LOD scores corresponding to $p=0.1$ were observed. Twodimensional, two-QTL scans were also performed using the scantwo function, using significance thresholds determined from 1000 permutations, but these did not reveal any additional QTL. The QTL positions were then refined using the fitqtl command, which also provided estimates of the percentage of phenotypic variation explained by each QTL. Interval estimates (95\% confidence) of QTL locations were obtained using the Bayes credible interval function (bayesint). For datasets displaying non-normal distributions, non-parametric tests were also performed. However, only one additional QTL was detected using this method (total seeds in year 2 for mapping population G33 $\times$ G43, Table 6). Finally, composite interval mapping was also performed using a window size of $10 \mathrm{cM}$, using three markers as co-variables. The outputs from these analyses are included within the plots for the QTL analyses shown in Additional file 5: Figure S2 and Additional file 8: Figure S5. The QTL effects (additive, dominant or overdominant) and source of the parental source of the beneficial alleles were determined by ANOVA analysis of the genotype versus phenotype at the QTL position, in conjunction with post hoc analysis using Tukey's test (Additional file 6: Figure S3 and Additional file 9: Figure S6).

\section{Additional files}

\section{Additional file 1: Table S1. Sequences for new SSR markers added to the linkage map}

Additional file 2: Table S2. Summary of genome sequence physically mapped onto the Jatropha curcas genetic map shown in Figure 1. Tables S3-S13. Summary of GenBank contigs mapped onto Groups 1 to 11 of the Jatropha curcas linkage map

Additional file 3: Table S14. Mapping of genes involved in seed oil biosynthesis onto the Jatropha curcas linkage map

Additional file 4: Figure S1. Distribution of trait data recorded for mapping population $\mathrm{G} 51 \times \mathrm{CV}$

Additional file 5: Figure S2. Initial QTL scans produced for traits recorded for mapping population $\mathrm{G} 51 \times \mathrm{CV}$

Additional file 6: Figure S3. Boxplots of genotype versus phenotype for QTLs in mapping population G51 × CV

Additional file 7: Figure S4. Distribution of trait data recorded for mapping population $\mathrm{G} 33 \times \mathrm{G} 43$

Additional file 8: Figure S5. Initial QTL scans produced for traits recorded for mapping population $\mathrm{G} 33 \times \mathrm{G} 43$

Additional file 9: Figure S6. Boxplots of genotype versus phenotype for QTLs in mapping population G33 × G43

Additional file 10: Phenotype and genotype date from mapping population G51 × CV

Additional file 11: Phenotype and genotype date from mapping population $\mathrm{G} 33 \times \mathrm{G} 43$

\section{Abbreviations}

ABA: abscisic acid; $A B I$ : ABA insensitive; ACP: acyl carrier protein; AFLP: amplified fragment length polymorphism; ANOVA: analysis of variance; CAS: Chinese Academy of Sciences; cM: centimorgan; CoA: coenzyme A; DGAT: diacylglycerol acyltransferase; ER: endoplasmic reticulum; FAD: fatty acyl desaturase; GWAS: genome-wide associated study; LOD: logarithm of odds; Mbp: megabase pairs; NMR: nuclear magnetic resonance; PAP: phosphatidate phosphatase; PVE: phenotypic variance explained; QTL: quantitative trait locus/loci; SNP: single nucleotide polymorphism; SSR: simple sequence repeat.

\section{Authors' contributions}

AJK, LRM, JGC, CAAP, REEJ, RGFV, ENVL and IAG designed research. AJK, LRM, JGC and JI conducted the research. AJK, LRM and JGC analysed the data. AJK wrote the manuscript. All authors reviewed the manuscript. All authors read and approved the final manuscript.

\section{Author details}

1 Department of Biology, Centre for Novel Agricultural Products, University of York, York YO10 5DD, UK. ${ }^{2}$ Biocombustibles de Guatemala, Guatemala Ciudad, Guatemala. ${ }^{3}$ Wageningen UR Plant Breeding, Wageningen University and Research Centre, PO Box 386, 6700 AJ Wageningen, The Netherlands.

${ }^{4}$ Graduate School of Experimental Plant Sciences, Wageningen University, Wageningen, The Netherlands. ${ }^{5}$ Wageningen UR Agrosystems Research, 
Wageningen University and Research Centre, PO Box 16, 6708 AP Wageningen, The Netherlands. ${ }^{6}$ Facultad de Agronomia, Universidad de San Carlos de Guatemala, Edifico T-8 y T-9 Ciudad Universitaria zona 12, Guatemala Cuidad, Guatemala.

\section{Acknowledgements}

The authors thank Dr. Xabier Barandiaran for his support in developing the field trials in Guatemala, Ricarda Orellana de Portillo for administrative support in Guatemala and Judith Mitchell for administrative support in York. This work was partly funded by a European Union Framework 7 Program Knowledge Based Bio-Economy grant under contract 245236. JGC was funded by a Biotechnology and Biological Sciences Research Council (BBSRC) Targeted Priority Studentship (Bioenergy, BB/G016801/1).

\section{Compliance with ethical guidelines}

\section{Competing interests}

The authors declare that they have no competing interests.

\section{Received: 3 March 2015 Accepted: 25 August 2015}

Published online: 25 September 2015

\section{References}

1. King AJ, He W, Cuevas JA, Freudenberger M, Ramiaramanana D, Graham IA (2009) Potential of Jatropha curcas as a source of renewable oil and animal feed. J Exp Bot 60(10):2897-2905

2. Yi C, Reddy C, Varghese K, Bui T, Zhang S, Kallath M, Kunjachen B, Ramachandran S, Hong Y (2014) A new Jatropha curcas variety (JO S2) with improved seed productivity. Sustainability 6(7):4355-4368

3. Kalannavar VN, Angadi SS, Patil VC, Byadagi AS, Patil SJ, Angadi SG (2009) Effect of major nutrients on growth and yield of Jatropha curcas. Karnataka J Agric Sci 22(5):1095-1096

4. Yang C, Fang Z, Li B, Liu G, Li J (2010) Breeding of high-oil Jatropha curcas L for biodiesel production. Chin J Biotechnol 26(11):1514-1525

5. Spinelli VS, dos Santos Dias LA, Rocha RB, Vilela Resende MD (2014) Yield performance of half-sib families of physic nut (Jatropha curcas L.). Crop Breed Appl Biotechnol 14:49-53

6. Mohapatra S, Panda PK (2011) Effects of fertilizer application on growth and yield of Jatropha curcas L. in an aeric tropaquept of Eastern India. Not Sci Biol 3(1):95-100

7. Heller J (1996) Physic Nut. Jatropha curcas L. Promoting the conservation and use of underutilized and negleted crops. Institure of Plant Genetics and Crop Research, International Plant Genetic Resource Institute, Gatersleben, Rome

8. Yue GH, Lo LC, Sun F, Cao SY, Yi CX, Hong Y, Sun WB (2014) No variation at 29 microsatellites in the genome of Jatropha curcas. J Genom 2:59-63

9. He W, King AJ, Khan MA, Cuevas JA, Ramiaramanana D, Graham IA (2011) Analysis of seed phorbol-ester and curcin content together with genetic diversity in multiple provenances of Jatropha curcas L. from Madagascar and Mexico. Plant Physiol Biochem 49(10):1183-1190

10. Osorio LRM, Salvador AFT, Jongschaap REE, Perez CAA, Sandoval JEB, Trindade LM, Visser RGF, van Loo EN (2014) High level of molecular and phenotypic biodiversity in Jatropha curcas from Central America compared to Africa, Asia and South America. BMC Plant Biol 14:77

11. Sun QB, Li LF, Li Y, Wu GJ, Ge XJ (2008) SSR and AFLP markers reveal low genetic diversity in the biofuel plant Jatropha curcas in China. Crop Sci 48(5):1865-1871

12. Pecina-Quintero $V$, Anaya-López JL, Zamarripa-Colmenero A, Núñez-Colín CA, Montes-García N, Solís-Bonilla JL, Jiménez-Becerril MF (2014) Genetic structure of Jatropha curcas L. in Mexico and probable centre of origin. Biomass Bioenergy 60:147-155

13. Pecina-Quintero V, Anaya-Lopez JL, Colmenero AZ, Garcia NM, Colin CAN, Bonilla JLS, Aguilar-Rangel MR, Langarica HRG, Bustamante DJM (2011) Molecular characterisation of Jatropha curcas L. genetic resources from Chiapas, Mexico through AFLP markers. Biomass Bioenergy 35(5):1897-1905

14. King A, Montes LR, Clarke JC, Affleck J, Li Y, Witsenboer H, van der Vossen E, van der Linde P, Tripathi Y, Tavares E et al (2013) Linkage mapping in the oilseed crop Jatropha curcas L. reveals a locus controlling the biosynthesis of phorbol esters which cause seed toxicity. Plant Biotechnol J 11(8):986-996
15. Makkar HPS, Aderibigbe AO, Becker K (1998) Comparative evaluation of non-toxic and toxic varieties of Jatropha curcas for chemical composition, digestibility, protein degradability and toxic factors. Food Chem 62(2):207

16. Liu P, Wang C, Li L, Sun F, Liu P, Yue G (2011) Mapping QTLs for oil traits and eQTLs for oleosin genes in jatropha. BMC Plant Biol 11(1):132

17. Sun F, Liu P, Ye J, Lo L, Cao S, Li L, Yue G, Wang C (2012) An approach for jatropha improvement using pleiotropic QTLs regulating plant growth and seed yield. Biotechnol Biofuels 5(1):42

18. Wu P, Zhou C, Cheng S, Wu Z, Lu W, Han J, Chen Y, Chen Y, Ni P, Wang Y et al (2015) Integrated genome sequence and linkage map of physic nut (Jatropha curcas L.), a biodiesel plant. Plant J 81:810-821

19. Hirakawa H, Tsuchimoto S, Sakai H, Nakayama S, Fujishiro T, Kishida Y, Kohara M, Watanabe A, Aizu T, Toyoda A et al (2012) Upgraded genomic information of Jatropha curcas L. Plant Biotechnol 29:123-130

20. Sato S, Hirakawa H, Isobe S, Fukai E, Watanabe A, Kato M, Kawashima K, Minami C, Muraki A, Nakazaki N et al (2011) Sequence analysis of the genome of an oil-bearing tree, Jatropha curcas L. DNA Res 18(1):65-76

21. Li-Beisson Y, Shorrosh B, Beisson F, Andersson MX, Arondel V, Bates PD, Baud S, Bird D, DeBono A, Durrett TP et al (2010) Acyl-Lipid Metabolism. Arabidopsis Book 8:e0133

22. Wang CM, Liu P, Yi C, Gu K, Sun F, Li L, Lo LC, Liu X, Feng F, Lin G et al (2011) A first generation microsatellite- and SNP-based linkage map of Jatropha. PLoS One 6(8):e23632

23. Eckardt NA (2006) Cytoplasmic male sterility and fertility restoration. Plant Cell 18(3):515-517

24. Sujatha M, Makkar HPS, Becker K (2005) Shoot bud proliferation from axillary nodes and leaf sections of non-toxic Jatropha curcas L. Plant Growth Regul 47(1):83

25. Knothe $\mathrm{G}$ (2005) Dependence of biodiesel fuel properties on the structure of fatty acid alkyl esters. Fuel Process Technol 86:1059-1070

26. Knothe G (2008) "Designer" biodiesel: optimizing fatty ester composition to improve fuel properties. Energy Fuels 22(2):1358-1364

27. King A, Li Y, Graham I (2011) Profiling the developing Jatropha curcas L. seed transcriptome by pyrosequencing. BioEnergy Res 4(3):211-221

28. Salas JNJ, Ohlrogge JB (2002) Characterization of substrate specificity of plant FatA and FatB acyl-ACP thioesterases. Arch Biochem Biophys 403(1):25-34

29. Schnurr JA, Shockey JM, de Boer G-J, Browse JA (2002) Fatty acid export from the chloroplast Molecular characterization of a major plastidial acylcoenzyme A synthetase from Arabidopsis. Plant Physiol 129(4):1700-1709

30. Yang $Y$, Yu $X$, Song $L, A n C$ (2011) ABI4 activates DGAT1 expression in Arabidopsis seedlings during nitrogen deficiency. Plant Physiol 156(2):873-883

31. To A, Valon C, Savino G, Guilleminot J, Devic M, Giraudat J, Parcy F (2006) A network of local and redundant gene regulation governs Arabidopsis seed maturation. Plant Cell 18(7):1642-1651

32. Jiang $H$, Wu P, Zhang S, Song C, Chen Y, Li M, Jia Y, Fang X, Chen F, Wu G (2012) Global analysis of gene expression profiles in developing physic nut (Jatropha curcas L.) seeds. PLoS One 7(5):e36522

33. Hobbs DH, Flintham JE, Hills MJ (2004) Genetic control of storage oil synthesis in seeds of Arabidopsis. Plant Physiol 136(2):3341-3349

34. Manichaikul A, Dupuis J, Sen Ś, Broman KW (2006) Poor performance of bootstrap confidence intervals for the location of a quantitative trait locus. Genetics 174(1):481-489

35. King AJ, Brown GD, Gilday AD, Larson TR, Graham IA (2014) Production of bioactive diterpenoids in the Euphorbiaceae depends on evolutionarily conserved gene clusters. Plant Cell 26(8):3286-3298

36. Beisson F, Koo AJK, Ruuska S, Schwender J, Pollard MR, Thelen JJ, Paddock T, Salas JJ, Savage L, Milcamps A et al (2003) Arabidopsis genes involved in acyl lipid metabolism. A 2003 census of the candidates, a study of the distribution of expressed sequence tags in organs, and a web-based database. Plant Physiol 132:681-697

37. Chinachoti P, Krygsman PH (2001) Application of low-resolution nmr for simultaneous moisture and oil determination in food (oilseeds). In: Current protocols in food analytical chemistry. Wiley, New York

38. Larson TR, Graham IA (2001) A novel technique for the sensitive quantification of acyl CoA esters from plant tissues. Plant J 25(1):115-125

39. Broman KW, Wu H, Sen Ś, Churchill GA (2003) R/qtl: QTL mapping in experimental crosses. Bioinformatics 19(7):889-890

40. Haley CS, Knott SA (1992) A simple regression method for mapping quantitative trait loci in line crosses using flanking markers. Heredity 69(4):315-324 